Mordensky Stanley, Paul (Orcid ID: 0000-0001-8607-303X)

Kennedy Ben (Orcid ID: 0000-0001-7235-6493)

Villeneuve Marlene, C (Orcid ID: 0000-0001-6001-0786)

Lavallée Yan (Orcid ID: 0000-0003-4766-5758)

Wallace Paul, A (Orcid ID: 0000-0003-2442-7386)

\title{
Increasing the permeability of hydrothermally altered andesite by transitory heating
}

S. P. Mordensky ${ }^{1}$; B. M. Kennedy ${ }^{1 *}$; M. C. Villeneuve ${ }^{1}$; Y. Lavallée $^{2}$; M. K. Reichow ${ }^{3}$; P. A. Wallace $^{2}$, P. A. Siratovich ${ }^{4}$, D. M. Gravley ${ }^{1}$

${ }^{1}$ Department of Geological Sciences, University of Canterbury, Private Bag 4800,

Christchurch 8140, New Zealand

\footnotetext{
${ }^{2}$ Department of Earth, Ocean and Ecological Sciences, University of Liverpool, Liverpool L69 3GP, UK
}

${ }^{3}$ School of Geography, Geology and the Environment, University of Leicester, University

Road, Leicester, LE1 7RH, UK

${ }^{4}$ Upflow Ltd., 3 Winston St., Acacia Bay, Taupo 3330, New Zealand

*Corresponding author

Corresponding author: first and last name (ben.kennedy@ canterbury.ac.nz)

\section{Key Points:}

- Heating of water-saturated hydrothermally altered andesite increases permeability stepwise between 100 and $800{ }^{\circ} \mathrm{C}$

- Alteration type and peak treatment temperature control the extent of permeability change, which can exceed one order of magnitude

Above $400{ }^{\circ} \mathrm{C}$, volume changes associated with heat-driven reactions contribute to microcracking and porosity/permeability changes

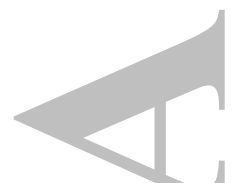

This article has been accepted for publication and undergone full peer review but has not been through the copyediting, typesetting, pagination and proofreading process which may lead to differences between this version and the Version of Record. Please cite this article as doi: 10.1029/2019GC008409 


\section{Abstract}

Changes in permeability can impact geological processes, geohazards, and geothermal energy production. In hydrothermal systems, high-temperature heat sources drive fluid convection through the pore network of reservoir rocks. Additionally, thermal fluctuations may induce microfracturing and affect the mineralogical stability of the reservoir rock, thus modifying the fluid pathways and affecting permeability and strength. This study describes the results of thermal heating events lasting several hours on a "moderately altered" plagioclase-clinochlore-calcite-quartz andesite and a "highly-altered" plagioclaseclinozoisite-quartz-clinochlore andesite from the Rotokawa geothermal field, New Zealand. We use a low thermal gradient $\left(\sim 1.2{ }^{\circ} \mathrm{C} / \mathrm{min}\right)$ in an $\mathrm{H}_{2} \mathrm{O}$-saturated, $20 \mathrm{MPa}$ pressure environment to constrain changes in petrophysical properties associated with transitory thermal phenomena between $350{ }^{\circ} \mathrm{C}$ and $739^{\circ} \mathrm{C}$. As the treatment temperature increases, the mass reduces, while porosity and permeability increase. These effects were greater in the "moderately altered" andesite than in the "highly altered" andesite. Microfracturing is responsible for these changes at lower temperatures (e.g. up to $400{ }^{\circ} \mathrm{C}$ ). At higher temperatures (e.g. $>400{ }^{\circ} \mathrm{C}$ ), microfracturing remains partially responsible for these rock property changes (e.g. higher permeability); however, these changes are also a product of clinochlore, quartz, and (when present) calcite reacting out of the altered andesite, and increasing porosity. We propose that at temperatures $>400{ }^{\circ} \mathrm{C}$, volumetric phase changes associated with heat driven reactions in a wet environment can contribute to micro-cracking and porosity/permeability changes. Our data support observations where high-temperature conditions at the margins of magma bodies can be associated with substantial increased permeability and decreased strength.

\section{Plain Language Summary}

Fluids squeeze through pathways in rocks to reach the surface. These pathways may consist of connected pores and/or cracks. Here we present experiments that test whether changes in temperature can create new fluid pathways in rocks from a geothermal reservoir. We slowly heat and cool the rocks to avoid shock heating, up to a maximum of $739{ }^{\circ} \mathrm{C}$ for approximately 30 hours. We find that even this short-term heating can generate large changes in the fluid pathways. New cracks form as temperature-sensitive minerals change in the rock. Our results show that heated rock around a magma chamber may allow more fluid to flow 
compared to ambient-temperature rock. The ability of rock around magma chambers to release fluid and gas is an important constraint when considering geothermal energy or the potential of a volcano to erupt.

\section{Introduction}

Hydrothermal fluids have long been sought for their utilisation as a heat source and conversion to electrical energy (Cataldi, 1993). Geothermal systems, especially those hosting an active hydrothermal system, provide a substantial resource to supply large populations with reliable, environmentally-friendly, sustainable energy. The driving geological components of a hydrothermal system (i.e. heat source, convecting fluid, and permeable conductive zone; Grant \& Bixley, 2011; Corrado et al., 2014) are complexly interrelated. Therefore, the interplay between these three variables is of utmost interest. Active magmatic provinces commonly host important hydrothermal systems, e.g. in the Central Chilean Andes (Grunder et al., 1987), North-Central Oregon (Ingebritsen et al., 1989), and the Taupo Volcanic Zone, New Zealand (Rowland \& Sibson, 2004). The thermal conditions directly adjacent to magmatic magma bodies may reach circa $1200{ }^{\circ} \mathrm{C}$ (Sigurdsson et al., 2000; and references therein), promoting vigorous fluid circulation (Scott et al., 2015). Although current geothermal boreholes rarely record temperatures $>350{ }^{\circ} \mathrm{C}$, this is largely due to current engineering limitations and associated risks; temperatures of $500-700{ }^{\circ} \mathrm{C}$ can be expected closer to magma bodies (Mortenson et al., 2014; Annen 2017). The profitable development of a geothermal power plant that uses high-enthalpy fluids targets reservoir rock with a narrow range of permeability (Scott et al., 2015). In hydrothermal systems for which the reservoirscale rock mass permeability is lower than $10^{-16} \mathrm{~m}^{2}$, it is expected that heat transport is primarily controlled by conduction, which is substantially less efficient for heat transport than convection (Ingebritsen et al., 2006). In contrast, if the reservoir-scale rock mass permeability exceeds $10^{-14} \mathrm{~m}^{2}$, as may be possible if fractures are present (e.g., Heap and Kennedy 2016; Lamur et al., 2017; Eggertsson et al., 2018), fluid convection is too rapid to promote optimal enthalpy (Cathles, 1977; Norton \& Knight, 1977; Hayba \& Ingebritsen, 1997). Therefore, understanding the impacts of heat sources on adjacent host-rock permeability will serve to increase the efficiency of ongoing and future geothermal energy production efforts.

Hydrothermal systems are dynamic environments, in which heat, fluid composition, reservoir rock permeability and strength fluctuate. Thermal stressing may cause relative 
expansion of solid (e.g. mineral) phases in the host rock (e.g. Barlett, 1832; Rosenholtz \& Smith, 1941; Siratovich et al., 2015b). When the rock temperature surpasses those previously experienced, permanent damage may occur (i.e. the Kaiser effect; e.g. Wyering et al., 2014, and references therein). Thermal cracking during heating has been attributed to several processes: the mismatched thermal expansion of minerals, temperature gradients induced as a function of heating rate, anisotropic thermal diffusivity of minerals, the bursting of fluid inclusions, mineral decomposition and devolatilization (e.g. Simmons \& Cooper, 1978; Wong \& Brace, 1979; Lo \& Wai, 1982; Keshavarz et al., 2010; Heap et al., 2012). As rocks are weaker in tension than compression (e.g., Harnett, 2019), cooling may be more likely to induce thermal fractures than heating (for comparable rates of temperature changes in our experiments; $c f$, Heap et al., 2014b; Schaefer et al., 2015; Browning et al. 2016); especially with higher cooling rates as can be induced by ingress of cooler water (e.g., Siratovich et al., 2015a; Villeneuve and Siratovich, 2015; Eggertsson et al., 2018). Yet the microstructure of rocks is central to the development of thermal fractures (at the laboratory scale), as they favourably develop in intact material originally containing few fractures; if fractures are, however, initially abundant in a material, its propensity to thermally fracture lessens (e.g., Eggertsson et al., 2018). The generation of these thermal fractures augments the permeability of the rock (Kendrick et al., 2013; Heap et al., 2014b; Browning et al., 2016; Eggertsson et al., 2018). Hydrothermal fluids and heat input may also dissolve or break down rock-forming minerals, thus creating additional permeable porous pathways for fluid flow (e.g. Nemčok et al., 2007; Heap et al., 2012; Kanakiya et al., 2017; Cant et al., 2018; Farquharson et al., 2019). Alternatively, hydrothermal fluids may induce the precipitation of minerals (e.g. clays, salts, carbonates, silica polymorphs) within the pores and cracks (e.g. Rowland \& Sibson, 2004 Griffiths et al., 2016; Kanakiya et al., 2017) and thereby decrease permeability (e.g. Heap et al., 2017). The permeability evolution of the reservoir rock is ultimately governed by the temperature, stress field, and chemistry of the system (fluids and solids), which control fluid convection (Fournier, 1985; and references therein). Magma provides the heat in many hydrothermal systems. The intrusion and subsequent cooling of magma in host rock can (re)activate and/or modify hydrothermal systems (Cathles et al., 1997; Grant \& Bixley, 2011; Liotta et al., In Press). An extreme example of this was documented at Krafla volcano, Iceland (Mortensen et al., 2014; Scott et al., 2015), where large changes in rock mass properties were encountered during drilling close to an active shallow rhyolite magma body, providing evidence of the thermal and chemical impact of the magma body on the surrounding host rock. 
The effects of temperature on the physical, chemical, and mineralogical properties of volcanic rocks has been the subject of a range of studies (e.g. Kitao et al., 1990; Björnsson, 2004; Siratovich et al., 2015a,b; Browning et al., 2016), but the range of scenarios (e.g. heating versus cooling), conditions (e.g. magnitude of temperature fluctuations), and reservoir rock types (e.g. unaltered versus altered) has prevented the generalisation of the impact on the resultant reservoir rock permeability. For instance, cooling results in contraction, which may generate macroscopic thermal cracks to promote fluid flow (Lamur et al., 2018) yet it may also precipitate secondary mineralisation that can, through time, block otherwise permeable pathways (Heap et al., 2017). In contrast, the impact of temperature increase (e.g. from magma intrusion) on the resultant rock permeability remains poorly constrained (Gaunt et al. 2016; Kushnir et al., 2017) as it has received noticeably less attention than the influence of changes in pressures on permeability (e.g. Gudmundsson, 2006; 2011; Heap et al., 2014a; Lamur et al., 2017; Heap et al., 2017; Eggertsson et al., 2018; Cant et al., 2018). Understanding how the permeability of reservoir rock changes in response to thermal fluctuation is critical to elaborate solutions to maintain the economic potential of hydrothermal resources. In summary, previous experimental studies on the impact of heat on the physical properties of rock have occurred either in wet conditions at lower temperatures (Siratovich et al., 2015b) or high temperatures in dry conditions (e.g. Rocchi et al. 2004; Heap et al., 2013a, b), including on altered rocks (e.g., Heap et al., 2012), but (to our knowledge) no studies have focused on hydrothermally altered rocks collected from a geothermal well.

In this study, we expose water-saturated reservoir rock (i.e. two suites of andesite with propylitic alteration assemblages) from the Rotokawa geothermal field, New Zealand to high temperatures (up to $739^{\circ} \mathrm{C}$ ) lasting several hours (up to 30 hours total heating and cooling time with 30 mins at target temperature) to investigate the impact on porosity, permeability, and mineralogy.

1.1 Geological context of the Rotokawa hydrothermal system

New Zealand, a world leader in geothermal power, hosts the majority of its geothermal power production within the Taupo Volcanic Zone (TVZ; Fig. 1). The Rotokawa andesite, encountered at $1.5-2.5 \mathrm{~km}$ depth in the TVZ serves as the primary reservoir rock for the Rotokawa geothermal field. This system is $14 \mathrm{~km} \mathrm{NE}$ of Taupo and hosts > 13 production wells as part of a large industrial complex, producing $24 \mathrm{MWe}$ at the Rotokawa I power station and $140 \mathrm{MWe}$ at the Nga Awa Purua power station. 
The 1.9 Ma Rotokawa andesite has a primary composition of medium- to low-K, calcalkaline andesitic lavas; however, these lavas have undergone extensive propylitic hydrothermal alteration in a high-enthalpy hydrothermal system following their burial 0.340.30 Ma ago (Chambefort et al., 2014; McNamara et al., 2016). Pre-alteration mineralogy was predominantly composed of plagioclase and pyroxene phenocrysts in a microlitic groundmass consisting of plagioclase and titanomagnetite. Rock-fluid interaction variably altered the primary plagioclase to albite, adularia, calcite, pyrite, and epidote. Pyroxene crystals were partially to completely altered to chlorite, quartz, calcite, and epidote. The groundmass was replaced with chlorite, leucoxene, haematite, and silica minerals (see Siratovich et al., 2016).

The aqueous ion chemistry in the Rotokawa hydrothermal fluids varies spatially and temporally and is the product of interaction between the rock and meteoric, magmatic and/or connate fluids (Rowland \& Simmons, 2012; Siratovich et al., 2016). Consequently, the chemistry is partially dependent on the permeability of the crystallizing magma bodies and surrounding host rocks (Norton, 1984), leading to the high degree of alteration and rock property variability found in the hydrothermal system. The variation of in situ temperatures (currently reaching $340{ }^{\circ} \mathrm{C}$ ) and pressures at depths up to $\sim 1.5$ to $2 \mathrm{~km}$ (e.g. pore pressure from $0-20 \mathrm{MPa}$; lithostatic pressures from $0-60 \mathrm{MPa}$ with effective mean pressures of $0-$ $10 \mathrm{MPa}$; Davidson et al., 2012) throughout the andesites' history has promoted the spatial development of rocks with a range of mechanical and physical rock properties (Siratovich et al., 2012, 2014, 2016; Wyering et al., 2014; Massiot et al. 2017).

The mechanical and physical rock properties of the Rotokawa andesite are highly variable because the petrological properties of the rock varies with alteration facies over short distances (<0.5 m; Siratovich et al., 2016). Vesicles (commonly irregularly shaped), fractures, and inter-granular pore space are variably filled with secondary minerals (e.g. chlorite, quartz, epidote, and/or calcite; Siratovich et al., 2016). The intensity of alteration may evolve from moderate to high over short distances across transitions between the inner, coherent parts of lavas to more brecciated parts (Siratovich et al., 2016). Consequently, the samples collected from coring exhibit a spectrum of mechanical properties; for instance, highly altered samples are weaker and dilate less than moderately altered rocks during deformation in the brittle field, and microscopic damage is more diffuse in high-porosity than in low-porosity samples (Siratovich et al., 2016). 


\section{Materials and Methods}

We investigate the impact of thermal treatment on the porosity and permeability of hydrothermally altered andesite using two different mineral assemblages from the Rotokawa hydrothermal system; an altered plagioclase-clinochlore-calcite-quartz andesite, which we label the "moderately altered" andesite herein, and an altered plagioclase-clinozoisite-quartzclinochlore andesite, which we label the "highly altered" andesite herein. Spot cores of the moderately and highly altered Rotokawa andesite were obtained during the drilling of Rotokawa production wells RK28 and RK29, respectively (Fig. S1; Siratovich et al., 2016). The spot cores were further cored with a $20 \mathrm{~mm}$-diameter diamond bit. The samples were cut and ground to a length of $40 \mathrm{~mm}$. Before the temperature treatment, we characterised the physical rock properties of the samples to compare to those of post-treatment samples. Porosity and density were measured by the Archimedes triple weight method. P- and S-wave velocities were collected using a GCTS CATS interfaced with transducer-mounted piezoelectric quartz crystals operating at a $900 \mathrm{kHz}$ resonance frequency under unconfined atmospheric conditions. Permeability was collected using argon gas in the PDP-200 steadystate permeameter at an effective confining pressure of $1 \mathrm{MPa}$. See Mordensky et al. (2018) for additional details on physical characterization methods performed at the University of Canterbury. We ensured that the physical properties of the cores produced from each respective rock type (moderately and highly altered) were similar (i.e. porosity, permeability, p-wave velocity) so as to minimize the potential impact of sample variability in such heterogeneous materials.

\subsection{Thermal treatment}

Altogether, we thermally treated 18 samples (9 moderately altered and 9 highly altered, one for each target temperature) in the temperature-pressure Magma Brewery autoclave at the University of Canterbury, New Zealand (Fig. 2). A pump applied $20 \mathrm{MPa}$ pressure using distilled $\mathrm{H}_{2} \mathrm{O}$. The temperature was then raised to $350,400,450,500,550$, $600,650,700$, or $739^{\circ} \mathrm{C}$. As temperature increased, excess $\mathrm{H}_{2} \mathrm{O}$ was bled via a manual micro-metering pressure release valve from the confinement system to maintain $20 \mathrm{MPa}$ pressure. To minimise the generation of thermal cracks from thermal gradients caused by rapid heating (e.g. Todd, 1973; Richter \& Simmons, 1974; David et al., 1999; Siratovich et al., 2011; Browning et al., 2016) and thus concentrate our investigation on the impact of mineral instability on the resultant physical properties of the rock, we estimated the thermal 
diffusivity using the mineral conductivity and specific heat for the mineralogy of a typically altered Rotokawa andesite with 55\% plagioclase, 5\% each of quartz and calcite and 35\% chlorite as $1.8 \mathrm{e}^{-6} \mathrm{~m}^{2} / \mathrm{s}$. This is consistent with the values for upper mantle rocks in Gibert et al. (2003), and for Waiora Formation fresh andesites (Mielke et al. 2015). Based on a simplified version of the diffusivity equation given in Carslaw \& Jaeger (1959) and Gibert et al. (2003), and ignoring the impact of water in the pores, we estimate a theoretical heating rate $\approx$ radius $^{2} /$ thermal diffusivity $\approx 1.1^{\circ} \mathrm{C} / \mathrm{min}$. In order for most of our experiments to be at temperatures $>100{ }^{\circ} \mathrm{C}$ for less than 24 hours and to minimize safety issues we heated the cores at a rate of approximately $1.2^{\circ} \mathrm{C} / \mathrm{min}$ and cooled at a constant rate of approximately 1.1 ${ }^{\circ} \mathrm{C} / \mathrm{min}$ to ambient temperatures (Fig. 3). To assess the impact from exposure to high temperatures in an $\mathrm{H}_{2} \mathrm{O}$-saturated environment, we left them to dwell at the peak temperature for $30 \mathrm{~min}$. In order to avoid barometrically stressing the samples due to phase changes associated with the liquid-vapour phase transition during cooling, pressure was released to ambient atmospheric conditions $(\sim 50 \mathrm{kPa} / \mathrm{min})$ once the sample reached $390{ }^{\circ} \mathrm{C}$. After thermal treatment, the physical properties were characterised again.

\subsection{Scanning electron microscopy}

Energy-dispersive X-ray spectroscopy (EDS) analysis was completed using a JEOL IT-300 scanning electron microscope (SEM) interfaced with an Oxford X-MAX ${ }^{\mathrm{N}} 50$ with an accelerating voltage of $15 \mathrm{kV}$, a working distance of $10 \mathrm{~mm}$, a spot size equivalent to a 40 JEOL probe current as defined by Japan Electron Optics Laboratory Company Ltd. Samples were cut, ground, and polished using diamond-tipped instruments and then carbon coated. Backscattered electron images were collected for both sample suites on untreated, $400{ }^{\circ} \mathrm{C}$ treated, $600{ }^{\circ} \mathrm{C}$-treated and $739^{\circ} \mathrm{C}$-treated samples.

2.3 X-ray diffraction analysis

Sample compositions were determined by X-ray powder diffraction (XRD) analysis using a Bruker D8 Advance Bragg-Brentano theta-theta powder diffractometer at the University of Leicester, UK. The machine uses $\mathrm{Cu} \mathrm{K} \alpha$ radiation and is equipped with a LynxEye position-sensitive detector and a 90-position auto-sampler. The scan range was 4 to 90 degrees 2-theta, with a step size of 0.01 degrees and a scan rate of $0.5 \mathrm{~s}$ per step. Phase identification was carried out using DIFFRAC.EVA software, interfaced with the PDF-4 database from the International Centre for Diffraction Data (ICDD), Philadelphia, USA. This 
analysis was conducted on the original (untreated) moderately and highly altered samples as well as on the samples subjected to temperatures of $600{ }^{\circ} \mathrm{C}$ and $739{ }^{\circ} \mathrm{C}$.

2.4 Thermo-gravimetric analysis

Thermo-gravimetric (TG) analysis was conducted by simultaneous thermal analysis (STA) using a Netzsch STA 449 F1 Jupiter at the University of Liverpool, UK (see also Siratovich et al. (2015b) for details on the measurements of the Rotokawa andesites). Sample chips ( $\operatorname{circa} 50-60 \mathrm{mg}$ ) were oven dried at $70{ }^{\circ} \mathrm{C}$ for several hours and held in an air-tight desiccator for thermal equilibration to atmospheric temperature and to minimise the presence of residual water molecules (that could affect weight determination) prior to testing. The sample chips were then loaded in a platinum sample crucible in an atmosphere flushed by argon gas at a flow rate of $20 \mathrm{ml} / \mathrm{min}$. The sample assembly was heated at a rate of $5{ }^{\circ} \mathrm{C} / \mathrm{min}$ to $900{ }^{\circ} \mathrm{C}$, whilst measuring thermo-gravimetric changes in sample weight (at an accuracy of $\pm 25 \mathrm{ng}$ ), which may fluctuate due to reactions (e.g. dehydration, calcination or oxidation/reduction). These measurements were conducted on 6 samples (i.e. untreated, 600 ${ }^{\circ} \mathrm{C}$-treated, and $739{ }^{\circ} \mathrm{C}$-treated samples from the moderately and highly altered andesites).

\section{Results}

3.1 Microstructural and sample composition analysis

Thermal treatment induced microfracturing in both the moderately and highly altered andesite. In the moderately altered andesite the microfractures in the untreated samples are short ( $<200 \mu \mathrm{m}$ (Fig. 4a)), have narrow aperture, and are mostly independent of each other. Following treatment to $400{ }^{\circ} \mathrm{C}$ the microfractures, although more common and longer than in the untreated samples, remain short $(<300 \mu \mathrm{m})$, have narrow aperture and are predominantly independent of each other (Fig. 4b), whereas following treatment to $600{ }^{\circ} \mathrm{C}$ the microfractures are slightly wider, longer and more interconnected (Fig. 4c). After treatment to $739{ }^{\circ} \mathrm{C}$ long (> $500 \mu \mathrm{m}$ ) microfractures cross-cut phenocrysts and the groundmass, and have a wider aperture (Fig. 4d). The long, through-cutting microfractures intersect other microfractures.

In the highly altered andesite microfracture density and intersection are not as prevalent as in the moderately altered andesite. The microfracture length, density, width and interconnectedness are similar for the untreated sample as the sample treated to $400{ }^{\circ} \mathrm{C}$ (Fig. 
5a,b), while the density, width and interconnectedness all increase in the sample treated to $600{ }^{\circ} \mathrm{C}$ (Fig. $5 \mathrm{c}$ ). For the sample treated to $739^{\circ} \mathrm{C}$ long $(>500 \mu \mathrm{m})$ microfractures crosscutting phenocrysts and the groundmass are present, in addition to an increase in width and interconnectedness of the shorter microfractures (Fig. 5d). Also of note is that microfractures are predominantly within clinochlore, quartz and plagioclase phenocrysts.

The electron-dispersive X-ray spectroscopy (EDS) and X-ray powder diffraction (XRD) composition analyses produced generally consistent results. EDS shows that the moderately altered andesite is composed of plagioclase (45-55\%), clinochlore $(\mathrm{OH}-$ bearing, magnesium-rich chlorite; $30-35 \%)$, quartz $(5-10 \%)$, and calcite $(5-10 \%)$ phenocrysts with a groundmass predominated by $10-20 \mu \mathrm{m}$ interlocking crystals with the same composition as the phenocrysts (Fig. 6a). The highly altered andesite contains plagioclase (80 $-95 \%)$ and quartz $(5-20 \%)$ phenocrysts with interstitial clinochore. The plagioclase grains display varying states of partial alteration to clinozoisite $(10-30 \%)$. The $10-20 \mu \mathrm{m}$ crystalline groundmass is predominantly plagioclase and clinochlore with pores and traces of clinozoisite, quartz, and calcite (Fig. 6d).

The EDS results also highlight the textural differences between samples treated to different temperatures. In the treated samples, the clinochlore, quartz, and calcite have reaction textures not present in the control samples (Fig. 6). The moderately altered sample treated to $600{ }^{\circ} \mathrm{C}$ shows reaction textures at the quartz-clinochlore interfaces, but not at the quartz-calcite, nor the quartz-plagioclase interfaces (Fig. 6b). The moderately altered sample treated to $739{ }^{\circ} \mathrm{C}$ shows similar quartz interface textures, in which a substantial volume of clinochlore and quartz have reacted out of the rock, and additional reaction textures in the calcite phenocrysts (Fig. 6c). The highly altered sample treated to $600{ }^{\circ} \mathrm{C}$ shows minor reaction textures at the quartz-clinochlore interfaces, but not at the quartz-plagioclase interfaces (Fig. 6e), while the highly altered sample treated to $739^{\circ} \mathrm{C}$ shows similar quartz interface textures (Fig. 6f) with a breakdown texture visible in the clinochlore-quartzplagioclase groundmass. For all samples, the plagioclase and the clinozoisite do not display reaction textures.

The EDS mineralogy results for the untreated samples are confirmed by X-ray diffraction (XRD) analysis (Fig. S2). XRD analysis of the samples treated at $600{ }^{\circ} \mathrm{C}$ found the same phases as in the untreated samples, but did not detect clinochlore in samples treated at $739^{\circ} \mathrm{C}$. That is, XRD analysis only detected plagioclase, quartz, and calcite in the 
moderately altered samples treated at $739^{\circ} \mathrm{C}$ and plagioclase, quartz, and clinozoisite in the highly altered samples treated at $739{ }^{\circ} \mathrm{C}$.

3.2 Thermo-gravimetric analysis

The TG analyses of the control samples of moderately altered and highly altered andesites exhibit two reactions initiating around $500{ }^{\circ} \mathrm{C}$ and at $650{ }^{\circ} \mathrm{C}$ (Fig. 7). For the moderately altered sample treated to $739^{\circ} \mathrm{C}$, only one reaction is detected because the minerals involved in the reaction initiating at $500{ }^{\circ} \mathrm{C}$ are no longer present, while those of the second reaction initiating at $650{ }^{\circ} \mathrm{C}$ remain. In the discussion below we proposed possible reactions to explain these mass losses. For the highly altered andesites the second reaction is either very minor or does not occur.

The highly altered control samples have noticeably smaller total mass loss than the moderately altered samples during both reactions (mean mass loss for highly altered $0.05 \mathrm{~g}$, compared to $0.67 \mathrm{~g}$ for moderately altered (Table 1$)$ ). The highly altered sample subjected to $600{ }^{\circ} \mathrm{C}$ exhibits greater mass loss compared to its respective control sample. We note some weight loss at low temperatures $\left(<100^{\circ} \mathrm{C}\right)$ during STA in the highly altered sample treated to $739^{\circ} \mathrm{C}$. Siratovich et al. (2015b) observed comparable mass loss at similarly low temperatures in untreated samples from the Rotokawa andesite. When considered with the $\mathrm{XRD}$ analysis, this anomalous TG behaviour is most likely due to adsorbed atmospheric molecular water loss.

3.3 Pre- and post-treatment physical properties of the Rotokawa andesite

The untreated bulk rock density of the moderately altered andesite is higher than that of the highly altered andesite (Table 1). This distinction is the result of the difference in porosity between the two sample series and remains true irrespective of the temperature reached for the thermal treatments in this study (Table 1). It is also important to note that sample volume increased as a result of higher treatment temperatures $\left(>650{ }^{\circ} \mathrm{C}\right)$. Neither sample suite displays a systematic density evolution with temperature (Table 1); however, the density of both the moderately and highly altered andesites generally decreases with temperature of the thermal treatment. In general, the changes in bulk sample density are $<1 \%$ for thermal stressing to moderate temperatures $\left(350-500{ }^{\circ} \mathrm{C}\right)$ and decrease more (by $\left.>2 \%\right)$ at higher temperatures $\left(\geq 550^{\circ} \mathrm{C}\right.$ in the moderately altered andesite and $\geq 739^{\circ} \mathrm{C}$ in the highly altered andesite; Table 1). The temperature associated with the greatest changes in 
density correspond with the temperature at which the second reaction was initiated during the TG analyses (Fig. 7; Table 1).

Thermal treatment resulted in the creation of porosity for both moderately and highly altered andesites (Fig. 8a) with porosity increasing non-linearly with treatment temperature. The increase in porosity of the highly altered samples was less than that of the moderately altered samples. The moderately altered andesite suites exhibit consistently lower original (pre-treatment) permeability than the highly altered andesite (Table 1). The thermal treatment increased the permeability of the moderately altered andesite by up to one order of magnitude (Fig. 8b; Table 1); and by a smaller magnitude in the highly altered andesite. Larger changes in permeability generally coincide with larger changes in porosity (Fig. 9).

The initial P- and S-wave velocities of the moderately altered samples are generally higher than those of the highly altered samples (Table 1). Both series show an initial increase in P-wave velocity followed by a decrease as treatment temperature increases (Fig. 8c). While post-treatment $S$-wave velocity values are generally lower than the initial values, there is no clear relationship between treatment temperature and change in S-wave velocity (Table

1).

\section{Discussion}

4.1 Porosity and permeability

It is important to acknowledge that the original samples used in this study contain varying fractions of mineral phases (Figs. 4-6, S1, S2a,d) and spatially variable microstructure as the samples were sourced from a naturally occurring hydrothermal system. The compositional heterogeneity also explains the discrepancy between the TG, XRD, and the EDS results (i.e. phase(s) absent after 600 and $739{ }^{\circ} \mathrm{C}$ treatment). Therefore, the relative changes in physical properties between samples subjected to different temperature increments may not be entirely attributable to the different thermal conditions, as abundances of certain phases or structures may affect thermal susceptibility. Nonetheless, we observe that the physical properties of moderately and highly altered Rotokawa andesite change after exposure to temperatures as low as $350{ }^{\circ} \mathrm{C}$, and that temperature increase consistently results in an increase in porosity (Table 2). We attribute the observed porosity and permeability increase to a combination of mineralogical breakdown of clinochlore, quartz, and calcite and 
to microcracking resulting from inevitable small stresses induced by thermal gradients and reaction driven volume changes during both heating and cooling (Ryan et al. 1978;

Vinciguerra et al. 2005; Heap et al., 2014b; Browning et al. 2016; Lamur et al., 2018; Eggertsson et al., 2018). In addition, the altered samples are heterogeneous and crystalline and the assumptions used to calculate the appropriate heating and cooling rate may, therefore, lead to overestimation. Thermal gradients are unavoidable, although we endeavoured to minimise these to the extent that our experimental constraints allowed.

4.2 Porosity and permeability: mineralogical breakdown

Thermo-gravimetric changes during STA indicate mass loss events at temperatures consistent with previous studies on the Rotokawa andesitic lavas. Siratovich et al. (2015b) observe no significant change in sample mass after thermal treatment in altered andesites exposed to $<450{ }^{\circ} \mathrm{C}$, but observe mass loss exceeding $2 \%$ (in the case of the moderately altered andesite) and $\sim 1 \%$ (in the case of the highly altered andesite) following thermal treatment above $500{ }^{\circ} \mathrm{C}$ due to the breakdown of chlorite, quartz, and calcite, similar to what we observed in our STA analyses (Fig. 7). It is important to note that the treatment of the samples in our study occurred at high pressure (20 MPa) under water-saturated conditions (as opposed to the dry, ambient pressure conditions in the STA analysis); therefore, the reactions (and resultant physical changes) following the thermal treatment may not occur at exactly the same temperatures as in the STA analysis. For example, the second reaction in the moderately altered andesite begins at $\sim 650{ }^{\circ} \mathrm{C}$ (Fig. 7), substantial change in permeability around this temperature is not observed until $>700{ }^{\circ} \mathrm{C}$ (Fig. 8b).

The absence of clinochlore in the XRD data (Fig. S2) in samples treated at 600 and $739^{\circ} \mathrm{C}$ suggests that the total experimental time at elevated temperatures in our tests may have allowed complete reaction out of clinochlore in the part of the sample analysed for XRD. However, EDS mapping and backscattered imaging in other parts of the sample found clinochlore still present, but with clear reaction textures, showing that the reactions were not complete. Alternatively, although compositionally the same, the crystal structure of the clinochlore may have been sufficiently altered that it is no longer detected in XRD as clinochlore. This suggests the $>450^{\circ} \mathrm{C}$ temperature reactions from the STA analyses (Fig. 7) can be attributed to these phases and is consistent with the breakdown of chlorite-quartz into talc, cordierite, and water (Eq. 1) at $500-600{ }^{\circ} \mathrm{C}$ observed in other studies (e.g. Fleming \& Fawcett, 1976; Massonne \& Massonne, 1989; Vidal et al., 2001). 
Eq. 1 Clinochlore + Quartz $=$ Talc + Cordierite + water

$6 \mathrm{Mg}_{3} \mathrm{Al}_{2} \mathrm{Si}_{3} \mathrm{O}_{10}(\mathrm{OH})_{8}+29 \mathrm{SiO}_{2}=8 \mathrm{Mg}_{3} \mathrm{Si}_{4} \mathrm{O}_{10}(\mathrm{OH})_{2}+3 \mathrm{Mg}_{2} \mathrm{Al}_{4} \mathrm{Si}_{5} \mathrm{O}_{18} * 0.5 \mathrm{H}_{2} \mathrm{O}+14.5$

$\mathrm{H}_{2} \mathrm{O}$

(Eq.1 presents the Mg-rich end member of clinochlore)

We attribute the absence of the reaction products talc and cordierite in any of the chemical analyses to the incomplete nature of the reaction and the mechanical removal of these crystal phases as they formed by the water that was flushed through the open pore structures at the interface of quartz and clinochlore. This reaction could be reversible during cooling which could also explain the absence of talc and cordierite in the XRD and EDS data. However, we see no textural evidence for this in our SEM analysis, but rather observe large pores at the quartz-clinochlore interfaces seen in Fig 6c-f, further suggesting the removal of reaction products.

Additionally, calcite crystals in the moderately altered andesite have reaction textures after having been treated to $739^{\circ} \mathrm{C}$ (Fig. 6c). The relatively large second reaction observed in the TG analyses of the moderately altered andesite (Fig. 7a) is consistent with decarbonation reactions of calcite in this temperature range, as shown in Eq. 2 (e.g. Mollo et al., 2012; Heap et al., 2013b).

Eq. 2 Calcite $=$ Calcium oxide + Carbon Dioxide

$$
\mathrm{CaCO}_{3}=\mathrm{CaO}+\mathrm{CO}_{2}
$$

The reaction textures and associated microfractures in calcite exposed to high temperatures (Fig. 6c) supports this interpretation. The changes observed in the clinochlore, quartz, and calcite demonstrate the susceptibility of these minerals to thermally driven physical property changes with even short-duration high-temperature pulses. Volume changes associated with devolitisation and recrystallisation will also drive micropore and microcrack creation and widening at high temperatures (Siratovich et al., 2015b).

4.3 Porosity and permeability: microcracking 
The microstructure of rocks serves as a first-order control on their mechanical and physical properties (e.g. Heap et al., 2014b). This is especially important in a geological context where rocks may be subjected to microcracking imparted by strong temperature fluctuations and/or gradients (e.g. magmatic dike emplacement, contact metamorphism, cooling of magma bodies; Siratovich et al., 2015a, and references therein). Thermal treatment of rock cores conducted in an oven (heating all sides of a sample) has been shown to generate microcracks without preferred orientation, resulting in isotropic elastic wave velocities (e.g. Vinciguerra et al., 2005; Fortin et al., 2011; Siratovich et al., 2011; Heap et al., 2013a; Heap et al., 2014a; Browning et al., 2016). Browning et al. (2016) also suggest cooling-driven fracturing dominates over heating-driven fracturing, which is likely in our experiments (wherein our cooling rates are similar to our heating rates). In addition, the altered Rotokawa andesite is heterogeneous and crystalline, rather than homogeneous or glassy, and the assumptions made when calculating the heating and cooling rate based on mineral constituents to avoid thermal gradient induced cracking may overestimate the heating and cooling rate. Elastic wave velocity analysis of the heated samples in our study suggests that the microfracturing and/or mineralogical reaction(s) associated with the short-lived thermal treatment began to inhibit $\mathrm{P}$-wave velocity in samples subjected to temperatures $>600{ }^{\circ} \mathrm{C}$ (Fig. 8c). Post-treatment S-wave velocities, while slower than pre-treatment S-wave velocities (Table 1), do not display a relationship with temperature. This lack of correlation suggests the heterogenous distribution of crystal size and composition within the altered andesites led to the non-systematic increase in proportion and orientation of microfractures and pores (e.g. Simmons \& Cooper, 1978; Wong \& Brace, 1979; Lo \& Wai, 1982; Keshavarz et al., 2010), which then produced a complex interaction of S-wave splitting (see Ryall \& Savage, 1974). This is consistent with our backscattered electron images, which show that microfractures are predominantly absent and, when present, short, in untreated samples Figs. 4a and 5a), while more abundant, longer and wider microfractures in the samples treated to higher temperature are preferential to plagioclase and quartz phenocrysts (Figs. 4b-d and 5cd) and may be due to volumetric fluctuations driven by phase changes associated with reactions.

Porosity and permeability changes increase with higher treatment temperatures in both sample suites. At low treatment temperatures, microfracturing (e.g. Fig. 4b) imparts higher porosity and permeability, especially in the moderately altered andesite (Figs. 8, 9; Table 1). As temperature surpasses $>550{ }^{\circ} \mathrm{C}$, the temperature at which the TG data (Fig. 7) 
depict the initial (likely clinochlore-quartz) reaction Eq. 1, we observe an increase in the rate at which permeability changes relative to treatment temperature, suggesting mass loss associated with the quartz-clinochlore reations (Fig. 6b-c and e-f) contributes substantially to the increase in permeability above this temperature. The next increase in the rate of permeability change relative to treatment temperature is above the temperature of the second reaction, Eq. 2 (Figs. 7, 8b). In the highly altered andesite, changes in permeability and porosity do not appear to be as drastic as in the moderately altered andesite (Figs. 8b, 9), which we attribute to the lack of calcite and smaller amount of clinochlore observed in the chemical analysis and EDS, and hence fewer reactions associated with Eq. 1 and the complete absence of the reaction in Eq. 2.

At temperatures below the mineralogical reactions in both sample suites $\left(<500{ }^{\circ} \mathrm{C}\right)$, we attribute permeability changes to thermal gradient driven microfracturing mostly during cooling, but above the clinochlore-quartz reaction and the calcite decarbonation reaction temperatures, permeability change is driven by a combination of microfracturing and mineralogical reaction(s). We also note the increases in porosity and permeability in the highly altered samples are smaller and less systematic than in the moderately altered samples, which we suggest may reflect a more heterogeneous highly altered sample suite, lower abundance of clinochlore and absence of calcite.

It is important to note when applying these experiments to natural environments with temperature fluctuations and cycles, that repeated exposure to high temperatures may deviate from those of the single runs presented here due to hysteresis and the Kaiser affect (e.g. Yong \& Wang, 1980; Lavrov, 2005; Heap et al., 2013a; Heap et al., 2014b). Additionally, the rate of temperature change in nature (thermal gradient) adjacent to magma bodies are highly spatially, and temporally variable (Annen 2017). The rates used in this study are most applicable to areas within a few 10s of meters of a magma body, however, we acknowledge that on average heating and cooling rates further from a magma body are likely to be much slower than our experiments.

\section{Implications}

The experimental results indicate that even brief (30-min) excursions to higher temperatures may modify the mineralogical and physical (e.g. porosity and permeability) properties of altered volcanic rocks in active hydrothermal systems. Nevertheless, direct 
implications of our experiments are hampered by the inability of any geological experiment to truly represent the timescales, thermal variations, and fluid chemistry of the natural system. In particular a natural system may remain at elevated temperatures for much longer (Annen, 2017) and experience fluid injections of variable chemistry (e.g. Williams-Jones and Heinrich, 2005; Farquharson et al., 2019) which will have profound influences on the porosity-permeability evolution of the rock mass. These observations may have implications for a range of phenomena and applications (e.g. slope stability, seismic interpretation, and geothermal power production), which we evaluate here. However, before discussing the potential consequences of the data in this study, we highlight that several of the characterisation techniques (e.g. porosity, P-wave velocity, S-wave velocity) were performed under atmospheric or near-surface conditions (e.g. permeability). The data reported would likely differ slightly if characterisation had been completed under the pressure ( 20 MPa) and temperature $\left(>275^{\circ} \mathrm{C}\right.$ ) conditions commonly associated with the Rotokawa andesite reservoir rock. The microfractures created during thermal exposure would close as confining pressure increases; therefore, porosity and permeability would decrease, while P-wave and Swave velocities would increase.

\subsection{Reservoir geomechanics}

The data presented in this study show that porosity increases as treatment temperature increases (Fig. 8; Table 1). Generally, an increase in porosity is associated with a decrease in the strength of hydrothermally altered rock (e.g. Wyering et al., 2014, 2015; Mordensky et al., 2018). Weakening intact rock (i.e. rock at the sample scale) will affect the behaviour of the intact rock around the wellbore, for example contributing to changes in drilling performance (as shown in Wyering et al., 2017). Additionally, weakening intact rock will increase the susceptibility to instability-inducing processes like borehole breakout, which is associated with stress-induced shearing of the rock at the wellbore (Plumb and Hickman, 1985). At the reservoir scale, increasing porosity can lead to changes in the behaviour of rock from dilatant brittle fracture-dominated behaviour to compactant pore collapse-dominated behaviour (as shown in Heap et al., 2015), leading to different responses of the reservoir during fluid extraction and injection as the effective pressures change (as demonstrated in Siratovich et al., 2016).

5.2 Slope stability 
Weakening of intact rock also contributes to weakening rock masses (Hoek et al., 2013) and may compromise the structural stability of a volcanic edifice (e.g. Voight $\&$ Elsworth, 1997; Apuani et al., 2005; Moon et al., 2009; Takahashi \& Yakata, 2018). Volcanic rocks are frequently exposed to extreme temperatures and alteration (e.g. Rowland \& Simmons, 2012); the data we present in this study suggests that altered volcanic rock masses can be weakened by temperatures as low as $350{ }^{\circ} \mathrm{C}$. While it is worth noting that Heap et al. (2014b) concluded that exposing unaltered andesite to high temperatures $\left(450{ }^{\circ} \mathrm{C}\right)$ over short timescales (60-min) would not greatly affect edifice strength and that Rocchi et al. (2004) found temperatures $<600{ }^{\circ} \mathrm{C}(60$-min timescale) would not affect the strength of unaltered basalt, these volcanic materials were fresh and did not contain hydrothermally altered materials. This distinction is important because fresh, primary volcanic phenocrysts and groundmass are often microcracked (e.g. Heap et al., 2014b) as a result of their cooling histories (e.g. David et al., 1999; Vinciguerra et al., 2005). Hydrothermal alteration infills and/or seals these microfractures (e.g. Pola et al., 2012, 2014; Wyering et al., 2014, and references therein), which can strenghten a rock mass (e.g. Pola et al., 2012, 2014; Wyering et al., 2014, and references therein; Coats et al., 2019). In addition, hydrothermal alteration will change the mineral assemblage, changing the types of reactions possible during heating and cooling. Our data suggest that reheating to temperatures as low as $350{ }^{\circ} \mathrm{C}$ over short time scales (30-min) can permanently damage hydrothermal material through additional microcracking (Figs. 4, 10; e.g. David et al., 1999) and mineralogical reaction (Figs. 6, 7, e.g. Siratovich et al., 2015b). Therefore, the presence of alteration, especially when infilling original pores and microfractures, may increase the susceptibility of volcanic rock to thermal weakening. The variation in pre-treatment porosity between individual samples precluded the possibility of conducting meaningful strength tests in this study. We suggest future research with hydrothermally altered volcanics of similar porosity be conducted in order to observe the effect of high-temperature treatment on strength. Nonetheless, mass wasting event deposits are already linked with hydrothermally altered volcanics (e.g. Mt. Ruapehu, New Zealand (Hackett \& Houghton, 1989), Mt. Shasta, USA (Crandell, 1989), Citlaltépetl, Mexico (Carrasco-Núñez \& Gomez-Tuena, 1993), Mt. Rainier, USA (Reid et al., 2001)). Our data suggest that the hydrothermally altered rocks found in these mass collapse deposits contributed to the initial failure processes that initiated the mass wasting events.

5.2 Geothermal power 
Permeability plays a critical role in geothermal power production (e.g. Cathles, 1977; Norton \& Knight, 1977; Hayba \& Ingebritsen, 1997). This study suggests that the alteration assemblage and the degree of alteration of a rock determine the susceptibility of its physical properties (e.g. permeability) to change as a result of (re)exposure to high temperature (Figs. $4-8,10)$. In New Zealand, reservoir temperatures can reach $\sim 325^{\circ} \mathrm{C}$ (Siratovich et al., 2015b), however, rocks closer to magma bodies may have much higher temperatures (> 500 ${ }^{\circ} \mathrm{C}$ ) as constrained by drilling at Krafla volcano, Iceland (Mortenson et al., 2014); however, temperatures were likely $>900{ }^{\circ} \mathrm{C}$ before cooling from drilling fluids (Zierenberg et al., 2013). Additionally, numerical modelling suggests temperature $>700{ }^{\circ} \mathrm{C}$ can be expected immediately adjacent to magma bodies (Annen, 2017). Both sample suites experience the greatest change in permeability at temperatures $>550{ }^{\circ} \mathrm{C}$, but the permeability of the highly altered andesite does not appear to be comparatively as affected as, or correlate as strongly with, increasing temperatures as the moderately altered andesite (Fig. 8). Thicknesses of alteration haloes are highly variable, are affected by magma type, local geology, and intrusion style, and are difficult to map due to poor exposure (e.g. Shanks, 2012; Annen 2017). We therefore emphasize the importance of constraining the lithologies thermally stressed by geological processes or industrial development. Our data also suggest that zones of lower elastic wave velocities within a lithological unit could indicate higher permeability as a consequence of short-lived, high-temperature thermal treatment (Fig. 8c; Table 1).

6 Conclusions

In this study, we subject andesite lavas from the Rotokawa geothermal field with plagioclase-clinochlore-calcite-quartz and plagioclase-clinozoisite-quartz-clinochlore alteration assemblages to short-lived thermal treatment $\left(350-739^{\circ} \mathrm{C}\right)$ at a low thermal gradient $\left(\sim 1.2^{\circ} \mathrm{C} / \mathrm{min}\right)$ and constant pressure $(20 \mathrm{MPa})$. Increasing the thermal treatment temperature increased porosity (from $7.8 \%$ to $15.1 \%$ ) and permeability (from $10^{-18} \mathrm{~m}^{2}$ to $10^{-17}$ $\mathrm{m}^{2}$ ) while decreasing P-wave velocity (from 4253 to $3368 \mathrm{~m} / \mathrm{s}$ ) in the altered andesites. The effects of the thermal treatment appear greater in the moderately altered andesite than in the highly altered andesite. Previous studies have suggested that short-duration excursion to high temperatures of similar duration would not have significant impact on volcanics and, thereby, edifice strength, structural stability, and geothermal reservoir operation. Although more experiments are warranted to explore the impact on strength, our data suggest that hydrothermally altered andesite should be more susceptible to mineralogical and 
microstructural change than unaltered andesite to temperature fluctuations. These results demonstrate that the presence of altered material in a volcanic edifice may make the edifice more prone to failure when it experiences high-temperature fluctuations. Our data also show that alteration intensity and mineralogy partially control the degree to which heating and cooling change the petrophysics in the geothermal reservoir.

Acknowledgments

We greatly appreciate the help from Cheryl Haiden with the analytical XRD analysis at the University of Leicester. The authors of this study acknowledge the support of the UC Doctoral Scholarship, UC Mason Trust Fund, Hubert Curien Partnership (PHC) Dumont D'Urville travel grant (number 31950RK), MBIE catalyst grant "Energy straight from magma", and Mercury NZ Limited (formerly Mighty River Power) "Source to Surface" grant. Yan Lavallée acknowledges financial support from the European Research Council Starting Grant on Strain Localisation in Magma (SLiM, No. 306488) and research funds from Landsvirkjun National Power Company of Iceland (NÝR-20 - 2017).

We additionally thank The Rotokawa Joint Venture (Tauhara North No. 2 Trust and Mercury NZ Limited) for for providing the core.

The authors comply with FAIR Data standards. The data associated with this research are openly accessible in the OpenEI database for renewable energy:

https://openei.org/datasets/dataset/8ddf9c8f-aa24-4af8-8fa9-

9e0c66445979/resource/be8f0414-6495-43b3-be17-

defbc9828e58/download/rkaphysicalcharacteristics.xlsx

\section{References}

Annen, C. (2017). Factors affecting the thickness of thermal aureoles. Frontiers in Earth Science, 5, 82.

Apuani, T., Corazzato, C., Cancelli, A., \& Tibaldi, A. (2005). Stability of a collapsing volcano (Stromboli, Italy): limit equilibrium analysis and numerical modelling. Journal of Volcanology and Geothermal Research, 144(1-4), 191-210.

Barlett, W. H. C. (1832). Experiments on the expansion and contraction of building stones by variation of temperature. American Journal of Science and Arts, 22(1), 136-140. 
Björnsson, G. (2004). Reservoir conditions at 3-6 km depth in the Hellisheidi Geothermal Field, SW-Iceland, estimated by deep drilling, cold water injection and seismic monitoring. Paper presented at the Twenty-Ninth Workshop on Geothermal Reservoir Engineering, Stanford University, Stanford, California, USA, January 26-28.

Browning, J., Meredith, P. G., \& Gudmundsson, A. (2016). Cooling-dominated cracking in thermally stressed volcanic rocks. Geophys. Res. Lett., 42.

doi:10.1002/2016GL070532

Cant, J. L., Siratovich, P. A., Cole, J. W., Villeneuve, M. C., \& Kennedy, B. M. (2018). Matrix permeability of reservoir rocks, Ngatamariki geothermal field, Taupo Volcanic Zone, New Zealand. Geothermal Energy, 6(2).

Carslaw, N.S., and Jaeger, J.C., 1959. Conduction of Heat in Solids, Oxford Univ. Press, New York.

Carrasco-Núñez, G., \& Gomez-Tuena, A. (1993). A voluminous avalanche-induced lahar from Citlaltepetl Volcano, Mexico: implications for hazard assessment. Journal of Volcanology and Geothermal Research, 59, 35-46.

Cataldi, R. (1993). Review of historiographic aspects of geothermal energy in the Mediterranean and Mesoamerican areas prior to the Modern Age. Geo-Heat Center Quarterly Bulletin, 15(1).

Cathles, L. M. (1977). An analysis of the cooling of the intrusions by ground-water convection that includes boiling. Economic Geology, 72, 804-826.

Cathles, L. M., Erendi, H. J., \& Barrie, T. (1997). How long can a hydrothermal system be sustained by a single intrusive event. Economic Geology, 92, 766-771. doi:03610128/97/1946/766-65

Chambefort, I., Lewis, B., Wilson, C. J. N., Rae, A. J., Coutts, C., Bignall, G., \& Ireland, T. R. (2014). Stratigraphy and structure of the Ngatamariki geothermal system from new zircon U-Pb geochronology: implications for Taupo Volcanic Zone evolution. Journal of Volcanology and Geothermal Research, 274, 51-70. doi:10.1016/j.jvolgeores.2014.01.015

Coats R., Kendrick J.E., Wallace P.A., Miwa T., Hornby A.J. Matsushima T., \& Lavallée Y. (2018) Failure criteria for porous dome rocks and lavas: a study of Mt. Unzen, Japan. Solid Earth, 1-42. 
Corrado, S., Aldega, L., Celano, A. S., De Benedetti, A. A., \& Giordano, G. (2014). Cap rock efficiency and fluid circulation of natural hydrothermal systems by means of XRD on clay minerals (Sutri, Northern Latium, Italy). Geothermics, 50, 180-188. doi:10.1016/j.geothermics.2013.09.011

Crandell, D. R. (1989). Gigantic debris avalanche of Pleistocene age from ancestral Mount Shasta volcano, California, and debris-avalanche hazard zonation. US Geological Survey Bulletin, 1861.

David, C., Menéndez, B., \& Darot, M. (1999). Influence of stress-induced and thermal cracking on physical properties and microstructure of La Peyratte granite. International Journal of Rock Mechanics and Mining Sciences, 36(4), 433-448. doi:10.1016/s0148-9062(99)00010-8

Davidson, J. P., Siratovich, P. A., Wallis, I. C., Gravley, D., \& McNamara, D. (2012). Quantifying the stress distribution at the Rotokawa Geothermal Field. Paper presented at the New Zealand Geothermal Workshop (November), Auckland, New Zealand.

Eggertsson, G. H., Lavallée, Y., Kendrick, J. E., \& Markússon, S. H. (2018). Improving fluid flow in geothermal reservoirs by thermal and mechanical stimulation: The case of Krafla volcano, Iceland. Journal of Volcanology and Geothermal Research in prss, 114.

Farquharson, J. I., Wild, B., Kushnir, A. R., Heap, M. J., Baud, P., \& Kennedy, B. (2019). Acid-Induced Dissolution of Andesite: Evolution of Permeability and Strength. Journal of Geophysical Research: Solid Earth, 124(1), 257-273.

Fleming, P. D., \& Fawcett, J. J. (1976). Upper stability of chlorite+quartz in the system $\mathrm{MgO}-\mathrm{FeO}-\mathrm{AlrOs}-\mathrm{SiO} 2-\mathrm{H} 2 \mathrm{O}$ at 2 kbar water pressure. Amerincan Minerologist, 61, 1175-1193.

Fortin, J., Stanchits, S., Vinciguerra, S., \& Gueguen, Y. (2011). Influence of thermal and mechanical cracks on permeability and elastic wave velocities in a basalt from Mt. Etna volcano subjected to elevated pressure. Tectonophysics, 503, 60-74.

Fournier, R. O. (1985). The behavior of silica in hydrothermal solutions. Reviews in Economic Geology(2), 45-59. 
Gaunt, H.E., Sammonds, P.R., Meredith, P.G. \& Chadderton, A., 2016. Effect of temperature on the permeability of lava dome rocks from the 2004-2008 eruption of Mount St. Helens. Bulletin of Volcanology, 78(4), p.30.

Gibert, B., Seipold, U., Tommasi, A. \& Mainprice, D., 2003. Thermal diffusivity of upper mantle rocks: Influence of temperature, pressure, and the deformation fabric. Journal of Geophysical Research, 108(B8):2359.

Grant, M. A., \& Bixley, P. F. (2011). Geothermal Reservoir Engineering (Vol. 2nd Edition). San Diego, CA: Elsevier.

Griffiths, L., Heap, M.J., Baud, P. \& Schmittbuhl, J., 2017. Quantification of microcrack characteristics and implications for stiffness and strength of granite. International Journal of Rock Mechanics

Grunder, A. L., Thompson, J. M., \& Hildreth, W. (1987). The hydrothermal system of the Calabozos caldera, Central Chilean Andes. Journal of Volcanology and Geothermal Research, 32, 287-298.

Gudmundsson, A. (2006). How local stresses control magma-chamber ruptures, dyke injections, and eruptions in composite volcanoes. Earth-Science Reviews, 79, 1-31.

Gudmundsson, A. (2011). Rock Fractures in Geological Processes. United Kingdom: Cambridge University Press (CUP).

Hackett, W. R., \& Houghton, B. F. (1989). A facies model for a Quaternary andesitic composite volcano: Ruapehu, New Zealand. Bulletin of Volcanology, 51(1), 51-68.

Hayba, D. O., \& Ingebritsen, S. E. (1997). Multiphase groundwater flow near cooling plutons. J. Geophys. Res., 102, 12235-12252.

Heap, M. J., Baud, P., Meredith, P. G., Vinciguerra, S., \& Reuschlé, T. (2014a). The permeability and elastic moduli of tuff from Campi Flegrei, Italy: implications for ground deformation modelling. Solid Earth, 5(1), 25-44. doi:10.5194/se-5-25-2014

Heap, M. J., Farquharson, J.I., Baud, P., Lavallée, Y., Reuschlé, T. (2015). Fracture and compaction of andesite in a volcanic edifice. Bulletin of Volcanology 77, 55. doi: 10.1007/s00445-015-0938-7

Heap, M.J. \& Kennedy, B.M. (2016) Exploring the scale-dependent permeability of fractured andesite, Earth and Planetary Science Letters, 447, 139-150. 
Heap, M. J., Kennedy, B., Farquharson, J., Ashworth, J., Gilg, H. A., Scheu, B., et al. (2017). A multidisciplinary approach to quantify the permeability of a volcanic hydrothermal system (Whakaari/White Island, Taupo Volcanic Zone, New Zealand). Journal of Volcanology and Geothermal Research, 332, 88-108.

Heap, M. J., Lavallée, Y., Laumann, A., Hess, K., \& Dingwell, D. B. (2012). How tough is tuff in the event of fire? Geology, 40, 311-314.

Heap, M. J., Lavallée, Y., Laumann, A., Hess, K., Meredith, P. G., Dingwell, D. B., et al. (2013a). The influence of thermal-stressing (up to $1000{ }^{\circ} \mathrm{C}$ ) on the physical, mechanical, and chemical properties of siliceous-aggregate, high-strength concrete. Construction and Building Materials, 42(248-265).

Heap, M. J., Lavallée, Y., Petrakova, L., Baud, P., Reuschlé, T., Varley, N. R., \& Dingwell, D. B. (2014b). Microstructural controls on the physical and mechanical properties of edifice-forming andesites at Volcán de Colima, Mexico. Journal of Geophysical Research: Solid Earth, 119(4), 2925-2963. doi:10.1002/2013JB010521

Heap, M. J., Mollo, S., Vinciguerra, S., Lavallée, Y., Hess, K. U., Dingwell, D. B., et al. (2013b). Thermal weakening of the carbonate basement under Mt. Etna volcano (Italy): implications for volcano instability. Journal of Volcanology and Geothermal Research, 250, 42-60.

Hoek, E., Carter, T. G., \& Diederichs, M. (2013). Quantification of the Geological Strength Index. Paper presented at the 47th US Rock Mechanics/Geomechanics Symposium, San Francisco, CA.

Ingebritsen, S. E., Sanford, W., \& Neuzil, C. (2006). Groundwater in Geologic Processes (2nd ed.). New York, USA: Cambridge University Press.

Ingebritsen, S. E., Sherrod, D. R., \& Mariner, R. H. (1989). Heat flow and hydrothermal circulation in the Cascade Range, North-Central Oregon. Science, 243(4897), 14581462.

Kanakiya, S., Adam, L., Esteban, L., Rowe, M., \& Shane, P. (2017). Dissolution and secondary mineral precipitation in basalts due to reactions with carbonic acid. Journal of Geophysical Research, 122(6), 4312-4327

Kendrick, J. E., Smith, R., Sammonds, P., Meredith, P. G., Dainty, M., \& Pallister, J. S. (2013). The influence of thermal and cyclic stressing on the strength of rocks from 
Mount St. Helens, Washington. Bulletin of Volcanology, 75(7)(728).

doi:10.1007/s00445-013-0728-Z

Keshavarz, M., Pellet, F. L., \& Loret, B. (2010). Damage and Changes in Mechanical Properties of a Gabbro Thermally Loaded up to $1,000^{\circ}$ C. Pure and Applied Geophysics, 167(12), 1511-1523. doi:10.1007/s00024-010-0130-0

Kitao, K., Ariki, K., Hatakeyama, K., \& Wakita, K. (1990). Well Stimulation Using ColdWater Injection Experiments in The Sumikawa Geothermal Field, Akita Perfecture, Japan. Geothermal Resources Council Transactions, 14, 1219-1224.

Kushnir, A.R.L., Martel, C., Champallier, R., \& Wadsworth, F.B., 2017. Permeability evolution in variably glassy basaltic andesites measured under magmatic conditions. Geophysical Research Letters, 44(20).

Lamur, A., Kendrick, J.E., Eggertsson, G.H., Wall, R.J., Ashworth, J.D., \& Lavallée, Y. (2017) The permeability of fractured rocks in pressurised volcanic and geothermal systems, Scientific Reports.

Lamur, A., Lavallée, Y., Iddon, F., Hornby, A. J., Kendrick, J. E., von Aulock, F. W., \& Wadsworth, F. B. (2018). Disclosing the temperature of columnar jointing and fluid flow in lavas. Nature communications, 9, 1432. doi:10.1038/s41467-018-03842-4

Lavrov, A., 2005. Fracture-induced physical phenomena and memory effects in rocks: a review. Strain 41, 135-149.

Liotta, D., Brogi, A., Ruggieri, G., Rimondi, V., Zucchi, M., Helgadóttir, H. M., et al. (In Press). Fracture analysis, hydrothermal mineralization and fluid pathways in the Neogene Geitafell central volcano: insights for the Krafla active geothermal system, Iceland. Journal of Volcanology and Geothermal Research https://doi.org/10.1016/j.jvolgeores.2018.11.023.

Lo, K. Y., \& Wai, R. S. C. (1982). Thermal expansion, diffusivity, and cracking of rock cores from Darlington, Ontario. Canadian Geotechnical Journal, 19, 154-166.

Massiot, C., Nicol, A., McNamara, D. D., \& Townend, J. (2017), Evidence for tectonic, lithologic, and thermal controls on fracture system geometries in an andesitic hightemperature geothermal field, J. Geophys. Res. Solid Earth, 122, doi:10.1002/2017JB014121 
Massonne, H.-J., \& Massonne, H.-J. (1989). The upper thermal stability of chlorite + quartz: an experimental study in the system MgO-A12O3-SiO2-H2O. Journal of Metamorphic Geology, 7(6).

McNamara, D. D., Sewell, S. M., Buscarlet, E., \& Wallis, I. C. (2016). A review of the Rotokawa Geothermal Field, New Zealand. Geothermics, 59(B), 281-293. https://doi.org/10.1016/j.geothermics.2015.07.007

Mielke, P., Prieto, A., Bignall, G. \& Sass, I. 2015. Effect of Hydrothermal Alteration on Rock Properties in the Tauhara Geothermal Field, New Zealand. Proc. World Geothermal Congress, Melbourne, Australia, 19-25 April.

Mollo, S., Heap, M. J., Jezzi, G., Hess, K., Scarlato, P., \& Dingwell, D. B. (2012). Volcanic edifice weakening via decarbonation: a self-limiting process? Geophys. Res. Lett., $39(15)$.

Moon, V., Bradshaw, J., \& de Lange, W. (2009). Geomorphic development of White Island volcano based on slope stability modelling. Engineering Geology, 104, 16-30.

Mordensky, S. P., Villeneuve, M. C., Kennedy, B. M., Heap, M. J., Gravley, D., Farquharson, J. I., \& Reuschlé, T. (2018). Physical and mechanical property relationships of a shallow intrusion and volcanic host rock, Pinnacle Ridge, Mt. Ruapehu, New Zealand. Journal of Volcanology and Geothermal Research, 359(15), 1-20. doi:10.1016/j.jvolgeores.2018.05.020

Mortensen, A. K., Egilson, P., Gautason, B., Árnadóttir, S., \& Gudmundsson, A. (2014). Stratigraphy, alteration mineralogy,permeability and temperature conditions of well IDDP-1,Krafla,NE-Iceland. Geothermics, 49, 31-41. doi:10.1016/j.geothermics.2013.09.013

Nemčok, M., Moore, J. N., Christensen, C., Allis, R., Powell, T., Murray, B., \& Nash, G. (2007). Controls on the Karaha-Telaga Bodas geothermal reservoir, Indonesia. Geothermics, 36(1), 9-46. doi:10.1016/j.geothermics.2006.09.005

Norton, D. (1984). Theory of Hydrothermal Systems. Annual Review of Earth and Planetary Sciences, 12, 155-177.

Norton, D., \& Knight, J. (1977). Transport phenomena in hydrothermal systems: cooling plutons. American Journal of Science, 277, 937-981. 
Plumb, R. A, Hickman, H. S. (1985). Stress-induced borehole elongation: A comparison between the four-arm dipmeter and the borehole televiewer in the Auburn geothermal well. Journal of Geophysical Research 90(B7), 5513-5521.

Pola, A., Crosta, G., Fusi, N., Barberini, V., \& Norini, G. (2012). Influence of alteration on physical properties of volcanic rocks. Tectonophysics, 566-567, 67-86. doi:10.1016/j.tecto.2012.07.017

Pola, A., Crosta, G. B., Fusi, N., \& Castellanza, R. (2014). General characterization of the mechanical behaviour of different volcanic rocks with respect to alteration. Engineering Geology, 169, 1-13. doi:10.1016/j.enggeo.2013.11.011

Reid, M. E., Sisson, T. W., \& Brien, D. L. (2001). Volcano collapse promoted by hydrothermal alteration and edifice shape, Mount Rainier, Washington. Geology, 29(9), 779. doi:10.1130/0091-7613(2001)029<0779:vcpbha>2.0.co;2

Richter, D., \& Simmons, G. (1974). Thermal Expansion Behavior of Igneous Rocks. International Journal of Rock Mechanics and Mining Sciences, 11, 403-411.

Rocchi, V., Sammonds, P. R., \& Kilburn, C. R. J. (2004). Fracturing of Etnean and Vesuvian rocks at high temperatures and low pressures. Journal of Volcanology and Geothermal Research, 132(2-3), 137-157.

Rosenholtz, J. L., \& Smith, D. T. (1941). Linear thermal expansions and inversions of quartz, var. rock crystal. American Mineralogist, 26(2), 103-109.

Rowland, J. V., \& Sibson, R. H. (2004). Structural controls on hydrothermal flow in a segmented rift system, Taupo Volcanic Zone, New Zealand. Geofluids, 4(4), 259-283. doi:10.1111/j.1468-8123.2004.00091.x

Rowland, J. V., \& Simmons, S. F. (2012). Hydrologic, magmatic, and tectonic controls on hydrothermal flow, Taupo Volcanic Zone, New Zealand: Implications for the formation of epithermal vein deposits. Economic Geology, 107(3), 427-457. doi:10.2113/econgeo.107.3.427

Ryall, A., \& Savage, W. (1974). S-wave splitting; key to earthquake prediction? Bulletin of the Seismological Society of America, 64(6), 1943-1951.

Ryan, M.P. \& Sammis, C.G. (1978) Cyclic fracture mechanisms in cooling basalt. Geological Society of America Bulletin, 89(9), pp.1295-1308. 
Schaefer L., Kendrick J.E., Lavallée Y., Oommen T., \& Chigna G. (2015) Geomechanical rock properties of edifice forming basalt. Frontiers in Earth Science 3. doi.org/10.3389/feart.2015.00029

Scott, S. W., Driesner, T., \& Weis, P. (2015). Geologic controls on supercritical geothermal resources above magmatic intrusions. Nature communications, 6, 7837-7837. doi:10.1038/ncomms8837.

Shanks, W. C. (2012). Volcanogenic Massive Sulfide Occurrence Model. Retrieved from Reston, Virginia:

Sigurdsson, H., Houghton, B. F., McNutt, S. R., Rymer, H., Stix, J., \& McBirney, A. R. (2000). Encyclopedia of Volcanoes. Physics Today, 53(10), 84-85. doi:10.1063/1.1325206

Simmons, G., \& Cooper, H. W. (1978). Thermal cycling cracks in three igneous rocks. International Journal of Rock Mechanics and Mining Sciences, 15(145-148).

Siratovich, P., Villeneuve, M., Cole, J., Kennedy, B., \& Bégué, F. (2015a). Saturated heating and quenching of three crustal rocks and implications for thermal stimulation of permeability in geothermal reservoirs. Int J Rock Mech Min 80, 265-280.

Siratovich, P. Davidson, J., Villeneuve, M., Gravley, D., Kennedy, B., Cole, J. W. L., \& Price, L. (2012). Physical and Mechanical Properties of the Rotokawa Andesite From Production Wells Rk 27_L2, Rk 28 and Rk 30. New Zealand Geothermal Workshop 19-21 November, 7-7.

Siratovich, P. A., Heap, M. J., Villeneuve, M. C., Cole, J., Kennedy, B., Davidson, J. P., \& Reuschlé, T. (2016). Mechanical behaviour of the Rotokawa Andesites (New Zealand): insight into permeability evolution and stress-induced behaviour in an actively utilised geothermal reservoir. Geothermics, 64, 163-179.

doi:10.1016/j.geothermics.2016.05.005

Siratovich, P. A., Heap, M. J., Villeneuve, M. C., Cole, J. W., \& Reuschlé, T. (2014). Physical property relationships of the Rotokawa Andesite, a significant geothermal reservoir rock in the Taupo Volcanic Zone, New Zealand. Geothermal Energy, 2(1), 10-10. doi:10.1186/s40517-014-0010-4 
Siratovich, P. A., Sass, I., Homuth, S., \& Bjornsson, A. (2011). Thermal stimulation of geothermal reservoirs and laboratory investigation of thermally induced fractures.

Transactions - Geothermal Resources Council, 35 2, 1529-1535.

Siratovich, P. A., von Aulock, F. W., Lavallée, Y., Cole, J. W., Kennedy, B. M., \& Villeneuve, M. C. (2015b). Thermoelastic properties of the Rotokawa Andesite: A geothermal reservoir constraint. Journal of Volcanology and Geothermal Research, 301, 1-13. doi:10.1016/j.jvolgeores.2015.05.003

Takahashi, R. \& Yahata, M. (2018). Effects of subvolcanic hydrothermal systems on edifice collapses and phreatic eruptions at Tokachidake volcano, Japan. Journal of Volcanology and Geothermal Research, 352, 117-129. doi:

10.1016/j.jvolgeores.2018.01.014

Todd, T. (1973). Effect of cracks on elastic properties of low porosity rocks. (PhD), Massachusetts Institute of Tech, Cambridge, MA.

Vidal, O., Parra, T., \& Trotet, F. (2001). Thermodynamicmodel for Fe-Mg aluminous chlorite using data from phase equilibrium experiments and natural perlitic assemblages in the $100^{\circ}$ to $600{ }^{\circ} \mathrm{C}, 1$ to $25 \mathrm{~kb}$ range. American Journal of Science, $301,557-592$.

Villeneuve, M.C. \& Siratovich, P.A. (2015). Experimental and Numerical Modelling of Thermal Stimulation in Geothermal Core Studies. In Proc: 13th ISRM International Congress of Rock Mechanics, Montreal, Canada, 10-13 May.

Vinciguerra, S., Trovato, C., Meredith, P. G., \& Benson, P. M. (2005). Relating seismic velocities, thermal cracking and permeability in Mt. Etna and Iceland basalts. International Journal of Rock Mechanics and Mining Sciences, 42(7-8), 900-910. doi:10.1016/j.ijrmms.2005.05.022

Voight, B., \& Elsworth, D. (1997). Failure of volcano slopes. Geotechnique, 47(1), 1-31.

Williams-Jones, A.E. \& Heinrich, C.A.: 100th Anniversary special paper: Vapor transport of metals and the formation of magmatic-hydrothermal ore deposits, Economic Geology, $100,(2005), 1287-1312$.

Wilson, C. J. N., Houghton, B. F., McWilliams, M. O., Lanphere, M. A., Weaver, S. D., \& Briggs, R. M. (1995). Volcanic and structural evolution of Taupo Volcanic Zone, 
New Zealand: a review. Journal of Volcanology and Geothermal Research, 68(1-3), 1-28. doi:10.1016/0377-0273(95)00006-g

Wong, T. F., \& Brace, W. F. (1979). Thermal expansion of rocks: some measurements at high pressure. Tectonophysics, 57, 95-117.

Wyering, L. D., Villeneuve, M. C., Wallis, I. C., Siratovich, P. A., Kennedy, B. M., \& Gravley, D. M. (2015). The development and application of the alteration strength index equation. Engineering Geology, 199, 48-61. doi:10.1016/j.enggeo.2015.10.003

Wyering, L. D., Villeneuve, M. C., Wallis, I. C., Siratovich, P. A., Kennedy, B. M., Gravley, D. M., \& Cant, J. L. (2014). Mechanical and physical properties of hydrothermally altered rocks, Taupo Volcanic Zone, New Zealand. Journal of Volcanology and Geothermal Research, 288, 76-93. doi:10.1016/j.jvolgeores.2014.10.008

Wyering, L. D., Villeneuve, M. C., Kennedy, B. M., Gravley, D. M., Siratovich, P. A. (2017). Using drilling and geological parameters to estimate rock strength in hydrothermally altered rock - A comparison of mechanical specific energy, R/N-W/D chart and Alteration Strength Index. Geothermics 69, 119-131.

doi:10.1016/j.geothermics.2017.05.008

Yong, C. \& Wang, C.Y., 1980. Thermally induced acoustic emission in Westerly granite. Geophys. Res. Lett. 7, 1089-1092.

Zierenberg, R. A., Schiffman, P., Barfod, G. H., Lesher, C. E., Marks, N. E., Lowenstern, J. B., \& Friðleifsson, G. Ó. (2013). Composition and origin of rhyolite melt intersected by drilling in the Krafla geothermal field, Iceland. Contributions to Mineralogy and Petrology, 165(2), 327-347. 


\begin{tabular}{|c|c|c|c|c|c|c|c|c|c|c|c|c|c|c|c|}
\hline \multirow[t]{2}{*}{ Sample } & \multirow[t]{2}{*}{$\begin{array}{l}\text { Temp. } \\
\left({ }^{\circ} \mathrm{C}\right)\end{array}$} & \multicolumn{2}{|c|}{$\begin{array}{c}\text { Sample } \\
\text { Volume }\left(\mathrm{cm}^{3}\right)\end{array}$} & \multicolumn{2}{|c|}{ Mass (g) } & \multicolumn{2}{|c|}{$\begin{array}{l}\text { Density } \\
\left(\mathrm{kg} / \mathrm{m}^{3}\right)\end{array}$} & \multicolumn{2}{|c|}{$\begin{array}{c}\text { Porosity } \\
(\%)\end{array}$} & \multicolumn{2}{|c|}{$\begin{array}{l}\text { Permeability } \\
\left(\times 10^{-18} \mathrm{~m}^{2}\right)\end{array}$} & \multicolumn{2}{|c|}{$\begin{array}{c}\text { P-wave } \\
\text { Velocity } \\
(\mathrm{m} / \mathrm{s})\end{array}$} & \multicolumn{2}{|c|}{$\begin{array}{c}\text { S-Wave } \\
\text { Velocity } \\
(\mathrm{m} / \mathrm{s})\end{array}$} \\
\hline & & Pre & Post & Pre & Post & Pre & Post & Pre & Post & Pre & Post & Pre & Post & Pre & Post \\
\hline M10 & ontrol & 12.58 & & 31.23 & & 2439 & & 9.98 & & 1.63 & & 4069 & & 2335 & \\
\hline M2 & & 12.65 & 12.64 & 31.94 & 31.90 & 2508 & 2498 & 7.59 & 7.74 & 4.91 & 5.42 & 3862 & 3890 & 2066 & 1984 \\
\hline- & & 12.65 & 12.65 & 31.63 & 31.55 & 2504 & 2484 & 8.11 & 8.49 & 3.13 & 11.3 & 3958 & 3986 & 2177 & 1328 \\
\hline M3 & & 12.57 & 12.57 & 31.57 & 31.38 & 2488 & 2460 & 8.53 & 9.62 & 3.04 & 14.6 & 4044 & 3888 & 1748 & 1899 \\
\hline M5 & & 12.66 & 12.64 & 31.26 & 30.91 & 2451 & 2412 & 9.92 & 11.6 & 2.72 & 12.4 & 3913 & 4158 & 1944 & 1349 \\
\hline M8 & & 12.51 & 12.51 & 31.13 & 30.59 & 2452 & 2382 & 9.55 & 12.0 & 2.51 & 16.3 & 3990 & 3880 & 2168 & 1042 \\
\hline M9 & & 12.74 & 12.75 & 31.52 & 30.91 & 2486 & 2406 & 8.71 & 11.7 & 2.19 & 15.5 & 3980 & 4031 & 1666 & 1362 \\
\hline M7 & 650 & 12.71 & 12.78 & 31.57 & 30.94 & 2476 & 2402 & 8.71 & 12.2 & 2.08 & 32.0 & 3991 & 3809 & 2043 & 1802 \\
\hline M4 & 700 & 12.74 & 12.85 & 31.56 & 29.32 & 2476 & 2283 & 8.97 & 16.1 & 1.06 & 88.8 & 3887 & 3301 & 2498 & 1557 \\
\hline M6 & & 12.73 & 12.83 & 31.90 & 30.55 & 2505 & 2367 & 7.75 & 15.1 & 1.09 & 73.3 & 4253 & 3368 & 2416 & 2227 \\
\hline $\mathrm{H} 4$ & ntrol & 12.75 & & 29.16 & & 2287 & & 15.7 & & 112 & & 3777 & & 1933 & \\
\hline H6 & & 12.71 & 12.73 & 28.86 & 28.83 & 2285 & 2286 & 16.4 & 18.1 & 490 & 511 & 3450 & 3578 & 1967 & 1133 \\
\hline H3 & 00 & 12.62 & 12.67 & 28.43 & 28.32 & 2246 & 2245 & 18.5 & 20.3 & 805 & 875 & 3268 & 3300 & 1713 & 1525 \\
\hline $\mathrm{H} 2$ & & 12.69 & 12.77 & 28.39 & 28.24 & 2264 & 2262 & 17.4 & 19.3 & 762 & 848 & 3369 & 3514 & 1838 & 1346 \\
\hline H9 & & 12.75 & 12.75 & 29.03 & 28.94 & 2297 & 2295 & 15.2 & 17.2 & 326 & 351 & 3630 & 3564 & 1907 & 1658 \\
\hline H5 & 550 & 12.67 & 12.73 & 28.52 & 28.41 & 2278 & 2270 & 16.3 & 17.7 & 340 & 384 & 3596 & 3574 & 1827 & 1594 \\
\hline H10 & 600 & 12.71 & 12.72 & 29.20 & 29.08 & 2301 & 2267 & 14.7 & 16.5 & 146 & 228 & 3727 & 3550 & 2066 & 1755 \\
\hline $\mathrm{H} 8$ & & 12.68 & 12.91 & 29.07 & 28.93 & 2279 & 2260 & 15.5 & 18.0 & 287 & 467 & 3602 & 3156 & 1700 & 1556 \\
\hline H1 & 700 & 12.74 & 12.89 & 29.55 & 30.25 & 2335 & 2355 & 12.0 & 14.5 & 43.4 & 60.1 & 3869 & 3552 & 2020 & 1757 \\
\hline H7 & 739 & 12.68 & 12.92 & 29.13 & 28.69 & 2291 & 2233 & 14.9 & 20.2 & 204 & 256 & 3747 & 3178 & 2018 & 1416 \\
\hline
\end{tabular}

Table 1 Physical property data. "M" samples are moderately altered, and "H" samples are highly altered. White-background columns depict pre-treatment data. Grey-background columns depict post-treatment data. Standard Error $\leq 1 \%$ of the reported value 


\begin{tabular}{|c|c|c|c|c|}
\hline Treatment & $0-400{ }^{\circ} \mathrm{C}$ & $401-600{ }^{\circ} \mathrm{C}$ & $601-739^{\circ} \mathrm{C}$ & $739-0{ }^{\circ} \mathrm{C}$ \\
\hline ocess & $\begin{array}{l}\text { Minimal thermal } \\
\text { gradient driven } \\
\text { micro-fracture }\end{array}$ & $\begin{array}{l}\text { Quartz clinochlore } \\
\text { breakdown reaction }\end{array}$ & $\begin{array}{l}\text { Continued quartz clinochlore } \\
\text { breakdown reaction; } \\
\text { calcite devolatilization } \\
\text { reaction }\end{array}$ & $\begin{array}{l}\text { Likely thermal } \\
\text { gradient driven } \\
\text { microfractures }\end{array}$ \\
\hline & No change & $\begin{array}{l}\text { Distinct mass loss in STA; no } \\
\text { change in XRD }\end{array}$ & $\begin{array}{l}\text { Continued mass loss in the } \\
\text { STA; } \\
\text { no clinochlore in XRD }\end{array}$ & \\
\hline & $\begin{array}{l}\text { Small porosity, } \\
\text { permeability and } \\
\text { seismic velocity } \\
\text { change }\end{array}$ & $\begin{array}{l}\text { Small porosity, permeability } \\
\text { and seismic velocity change }\end{array}$ & $\begin{array}{l}\text { Large porosity, permeability } \\
\text { and seismic velocity change }\end{array}$ & \\
\hline $\begin{array}{l}\text { Microstructural and } \\
\text { textural evidence }\end{array}$ & $\begin{array}{l}\text { Minor increase in } \\
\text { microfracture length } \\
\text { and density; no } \\
\text { quartz-clinochlore } \\
\text { interface pores; } \\
\text { calcite unaffected }\end{array}$ & $\begin{array}{l}\text { Increase in microfracture } \\
\text { length, density, width and } \\
\text { interconnectedness; new } \\
\text { pores at quartz-clinochlore } \\
\text { interface; calcite unaffected }\end{array}$ & $\begin{array}{l}\text { Continued increase in } \\
\text { microfracture length, density, } \\
\text { width and } \\
\text { interconnectedness; new } \\
\text { pores at quartz-clinochlore } \\
\text { interface and within calcite; } \\
\text { calcite proportion reduced }\end{array}$ & \\
\hline
\end{tabular}

Table 2 Summary of interpreted alteration processes during heat treatment and cooling with associated evidence.

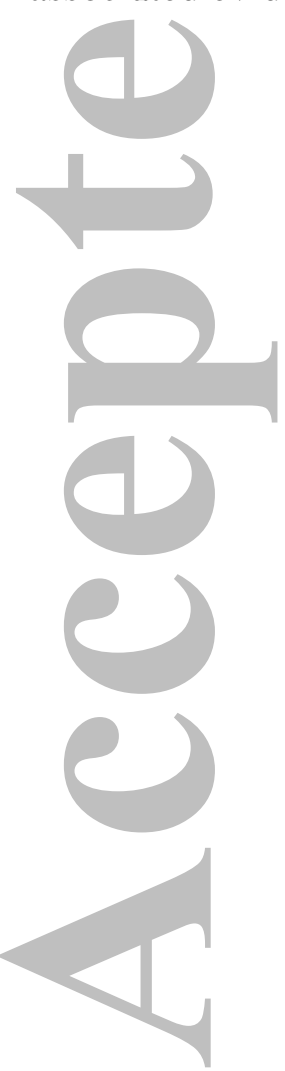




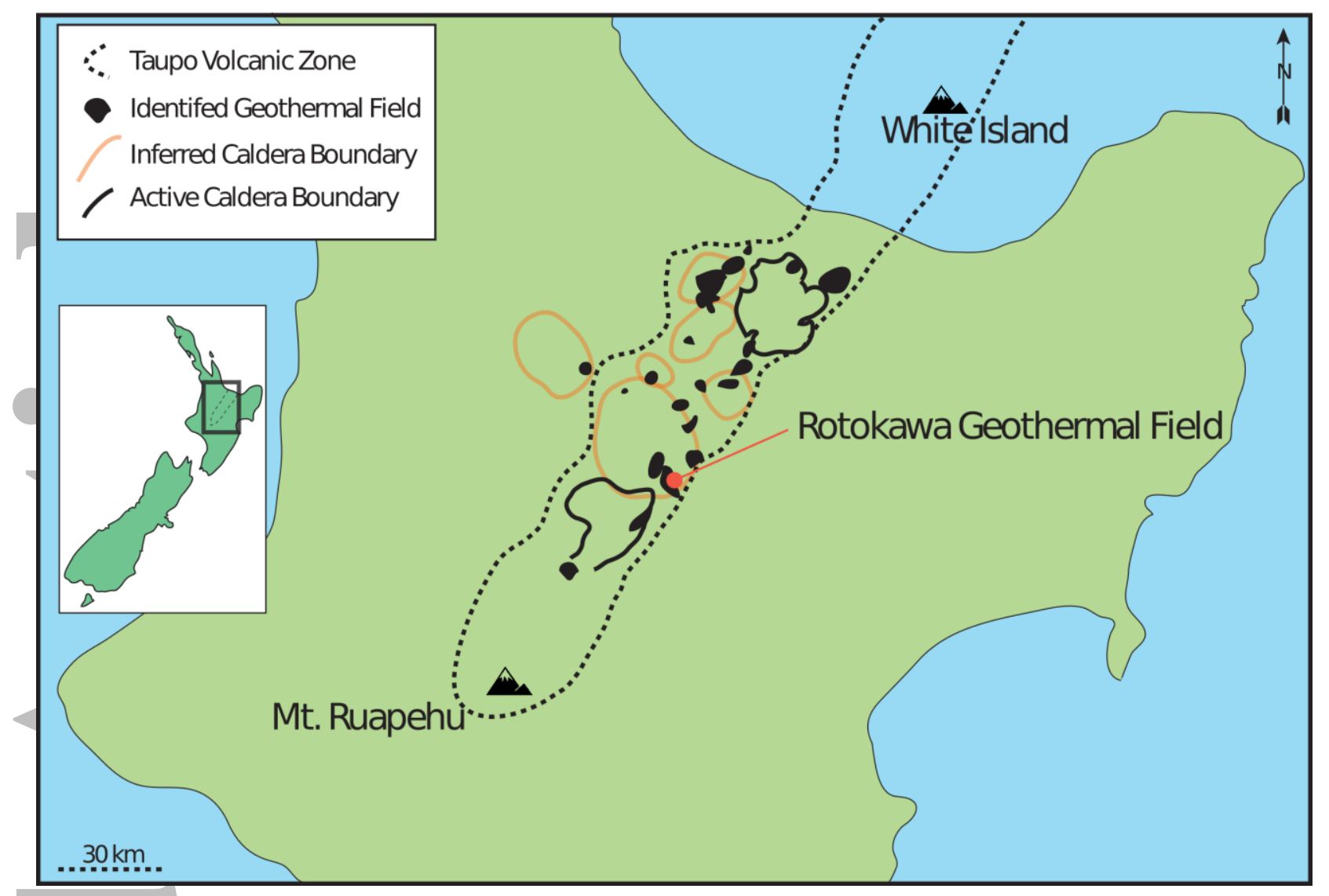

Figure 1. North Island, New Zealand and the active TVZ boundaries (dashed black) with the locations of geothermal fields (black), active caldera boundaries (black outline), and inferred caldera boundaries (orange outline). Rotokawa geothermal field indicated by red circle.

Adapted from Wilson et al. (1995). 


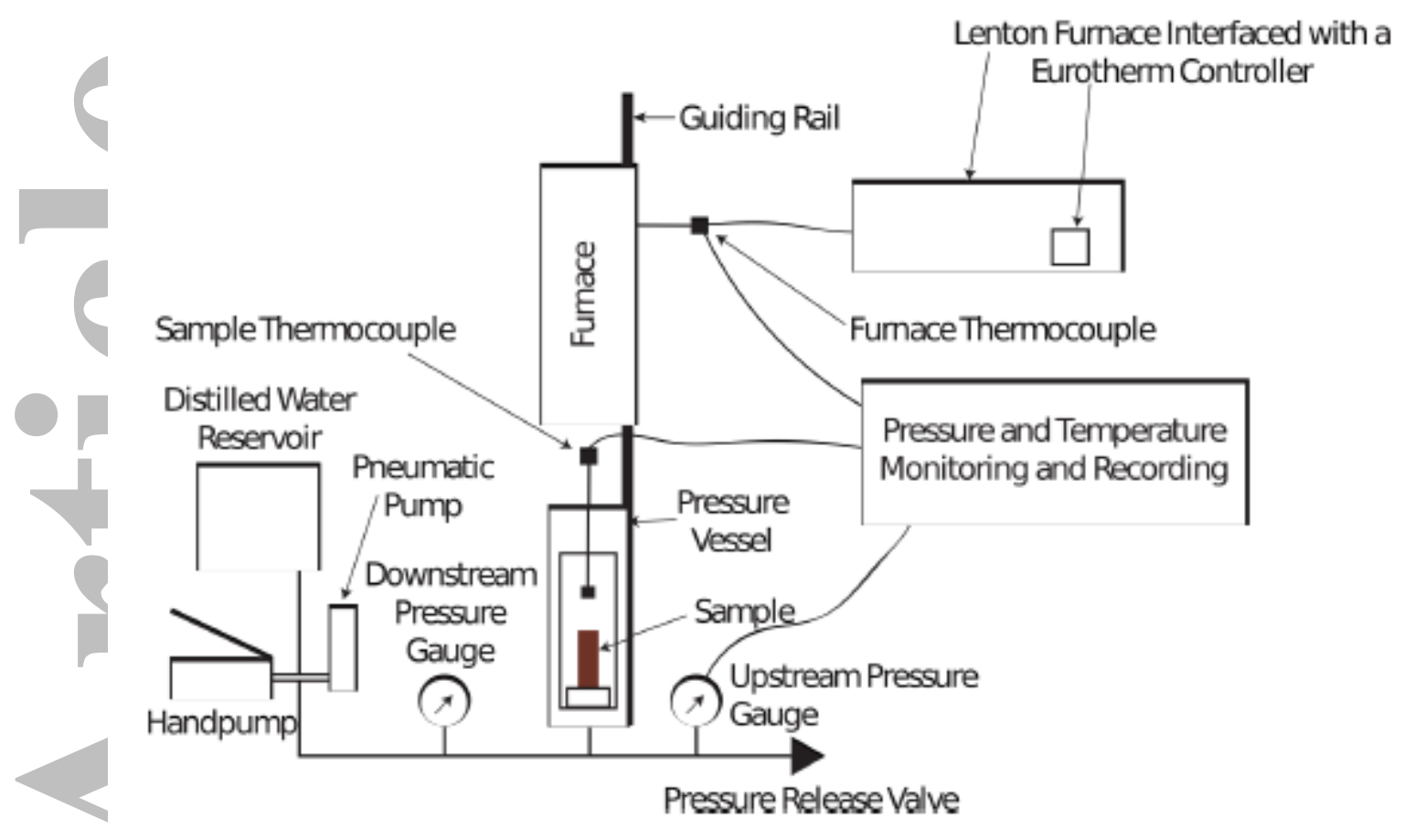

Figure 2. Schematic outline of the 'Magma Brewery' autoclave (diagram not to scale).

Furnace followed guiding rail down to envelope pressure vessel. This autoclave system has an operational limit of $739^{\circ} \mathrm{C}$.

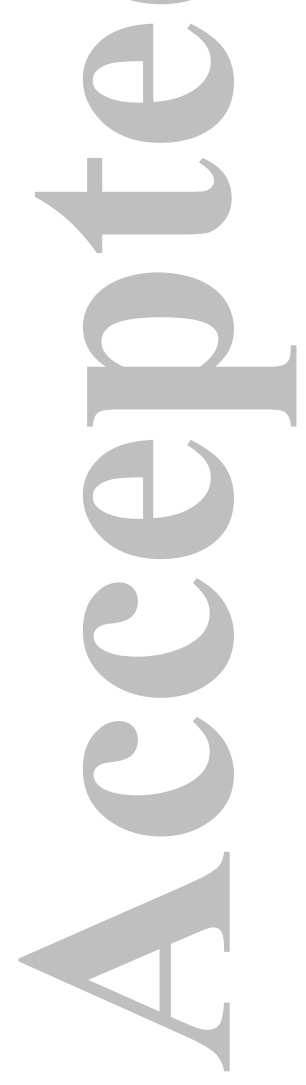




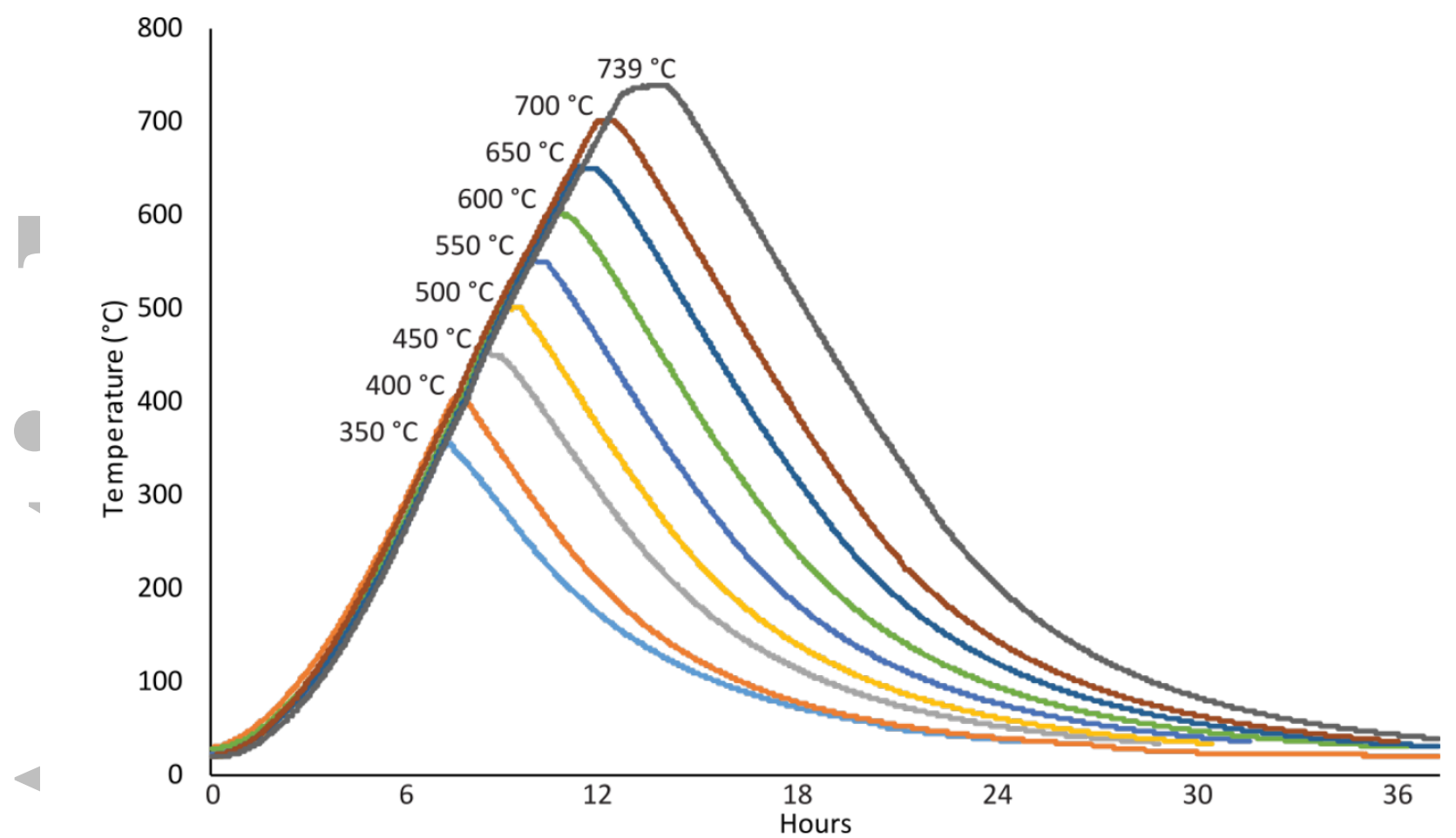

Figure 3. Heating and cooling profiles of thermal treatment of the Rotokawa andesite.

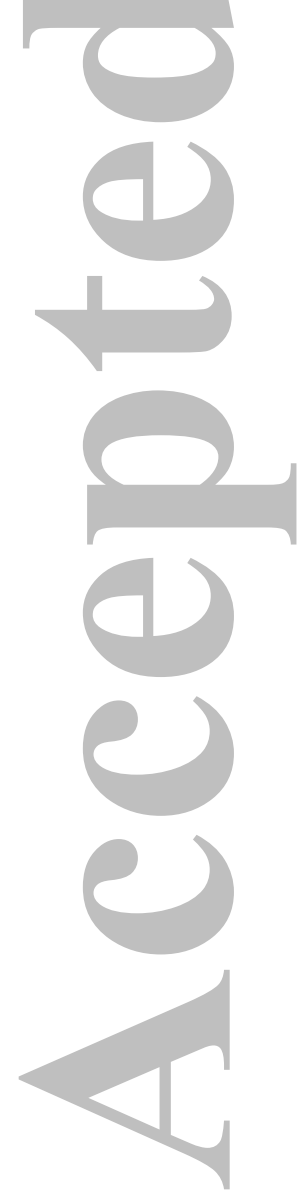




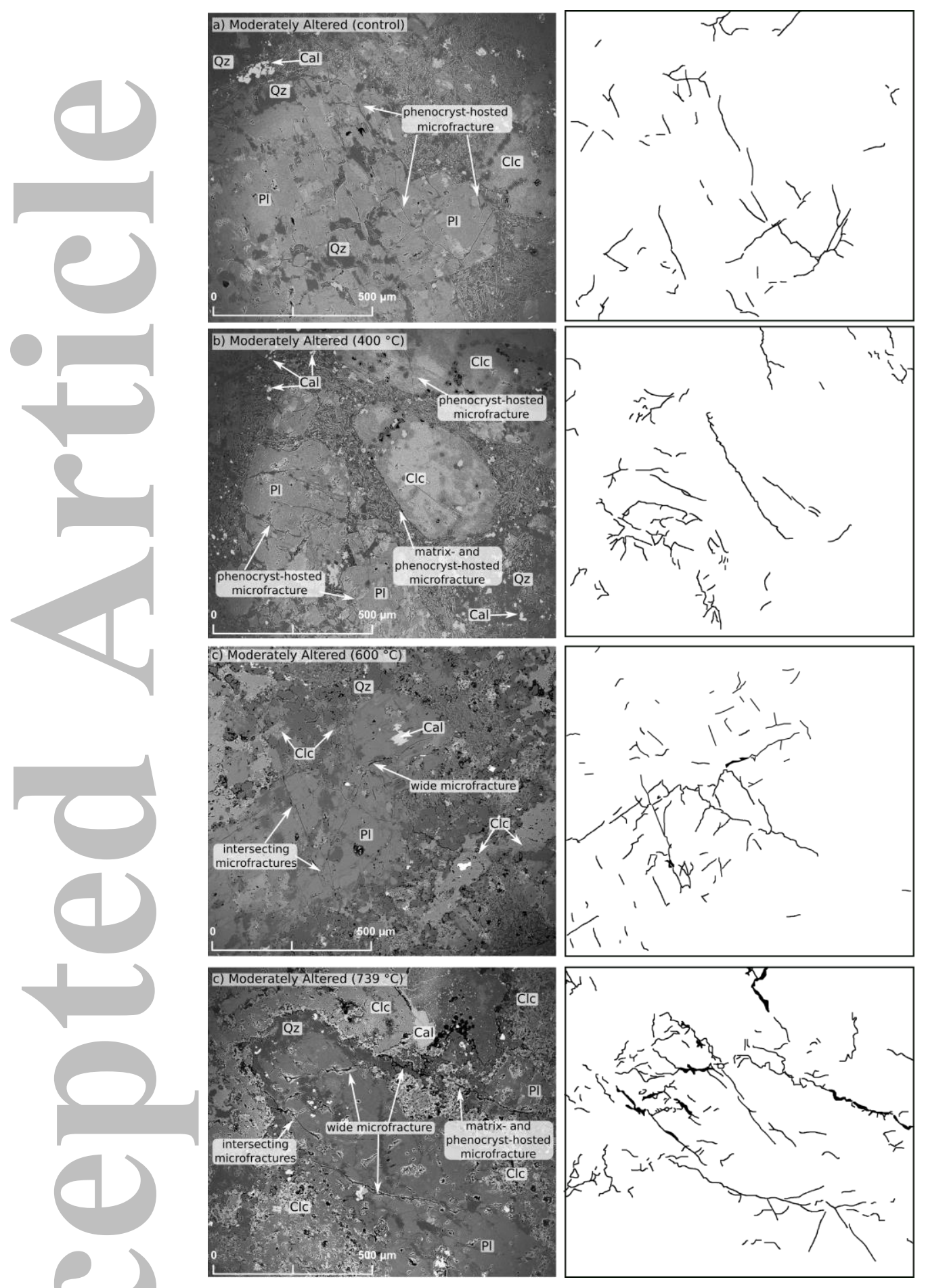

Figure 4. Backscattered electron images of sample microstructure of moderately altered andesite: (a) untreated; (b) treated at $400{ }^{\circ} \mathrm{C}$; (c) treated at $600{ }^{\circ} \mathrm{C}$; (c) treated at $739{ }^{\circ} \mathrm{C}$. (d) Porosity is black. Clinochlore (Clc), Quartz, (Qz), Plagioclase, (Pl) Calcite, (Cal). All images were collected at 100x magnification. 


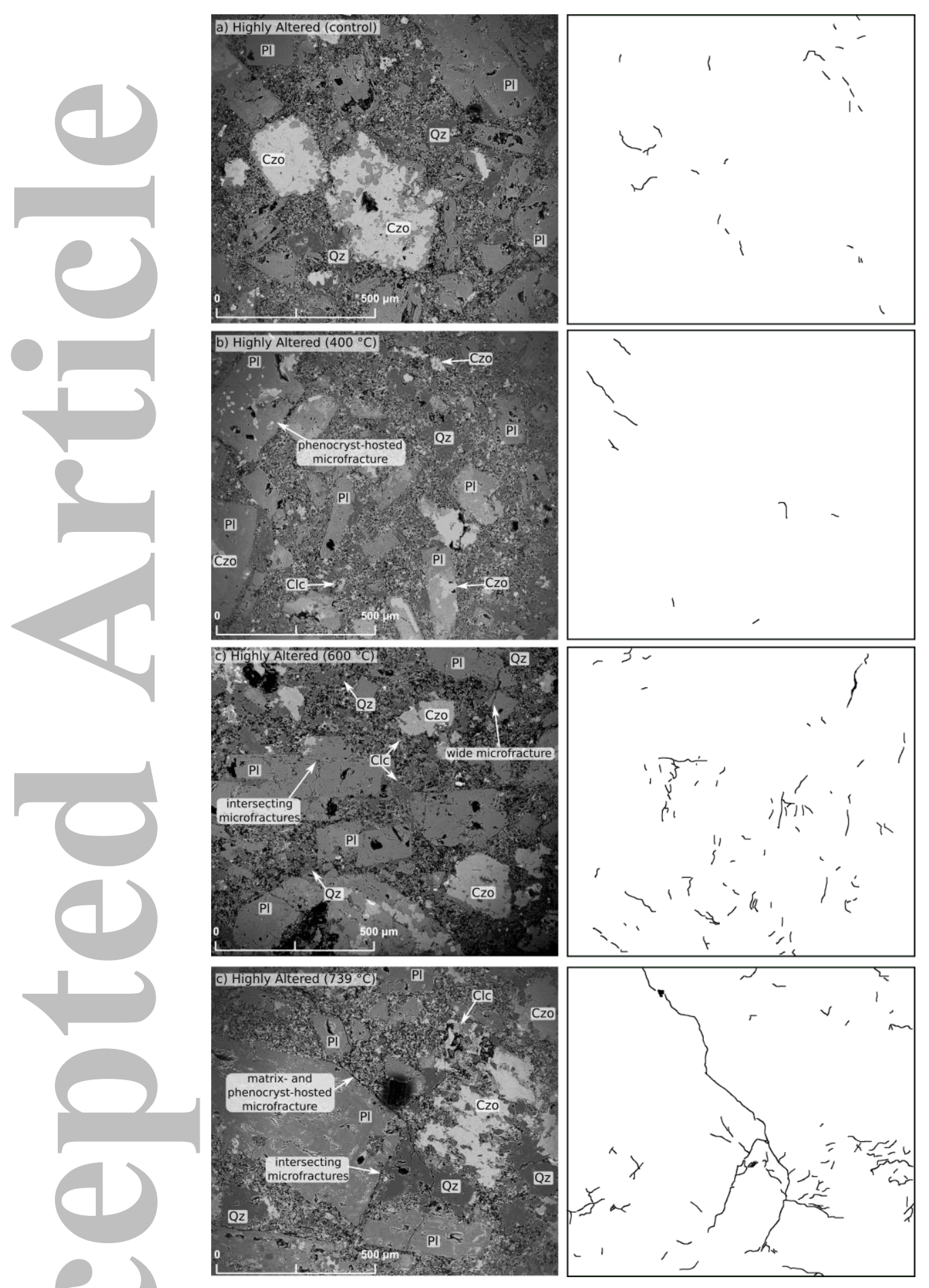

Figure 5. Backscattered electron images of sample microstructure of highly altered andesite: (a) untreated; (b) treated at $400{ }^{\circ} \mathrm{C}$; (c) treated at $600{ }^{\circ} \mathrm{C}$; (d) treated at $739{ }^{\circ} \mathrm{C}$. Porosity is black. Clinozoisite (Czo), Clinochlore (Clc), Quartz, (Qz), Plagioclase, (Pl). All images were collected at 100x magnification. 

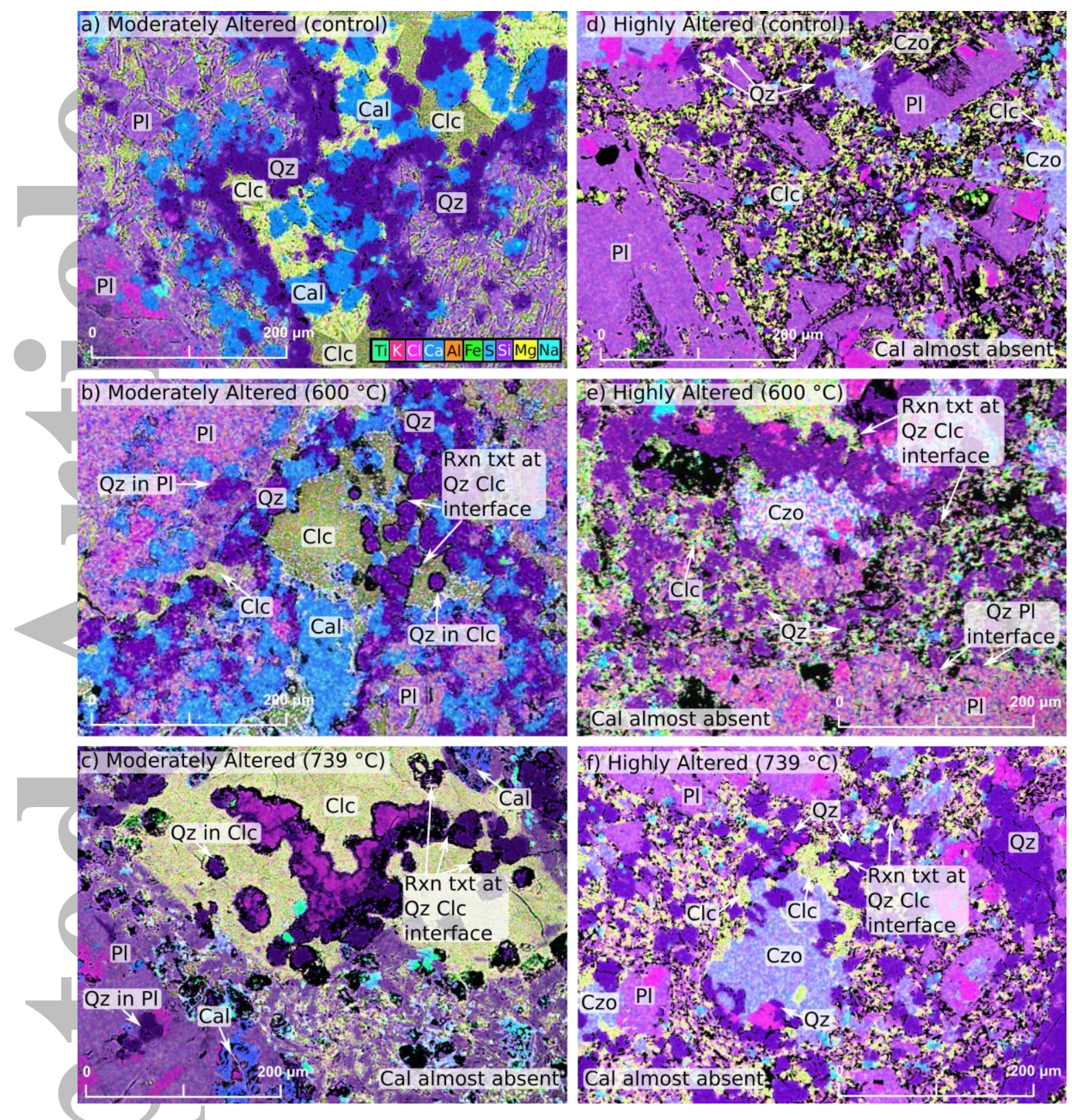

Figure 6. False colour images of sample mineralogy identified by EDS. (a) Untreated moderately altered andesite; (b) Moderately altered andesite treated at $600{ }^{\circ} \mathrm{C}$ with reaction textures in clinochlore and quartz; (c) Moderately altered andesite treated at $739{ }^{\circ} \mathrm{C}$ with reaction textures in clinochlore, quartz, and calcite; (d) Untreated highly altered andesite; (e) Highly altered andesite treated at $600{ }^{\circ} \mathrm{C}$ with minor reaction textures in clinochlore, quartz; (f) Highly altered andesite treated at $739^{\circ} \mathrm{C}$ with minor reaction textures in quartz and clinochlore. Examples of reaction textures (Rxn Txt) marked in treated samples. Porosity is black. Clinozoisite (Czo), Clinochlore (Clc), Quartz, (Qz), Plagioclase, (Pl) Calcite, (Cal). All images were collected at 150x magnification. 


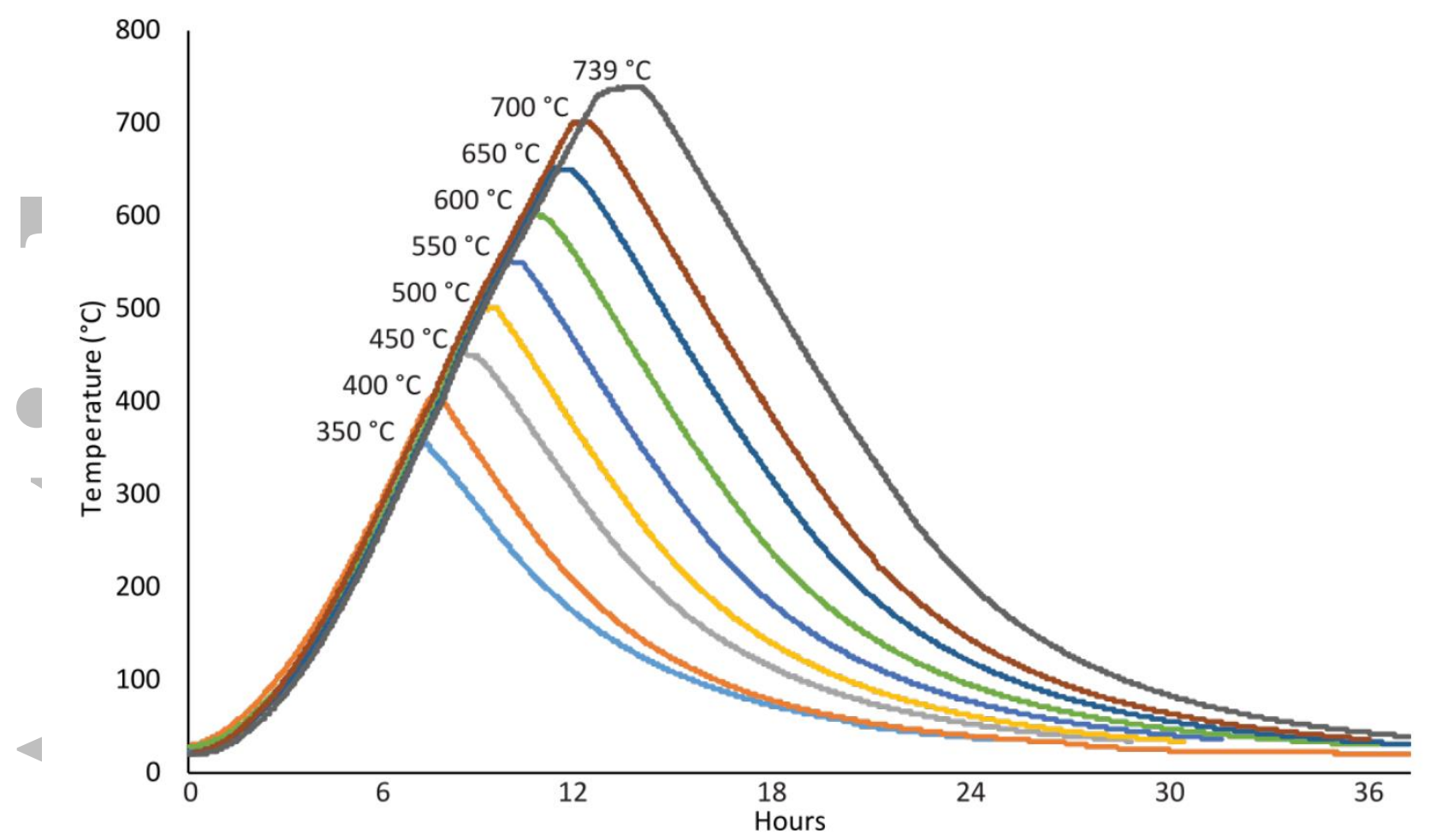

Figure 7. Results of thermo-gravimetric analysis for a) the moderately altered andesite (originally collected as well as previously heated to $600{ }^{\circ} \mathrm{C}$ and $739^{\circ} \mathrm{C}$ ) and b) the highly altered andesite samples. All samples display evidence of reactions initiating during heating beyond circa $500{ }^{\circ} \mathrm{C}$ and $650{ }^{\circ} \mathrm{C}$. Note the discrepancy in scale between (a) and (b). 

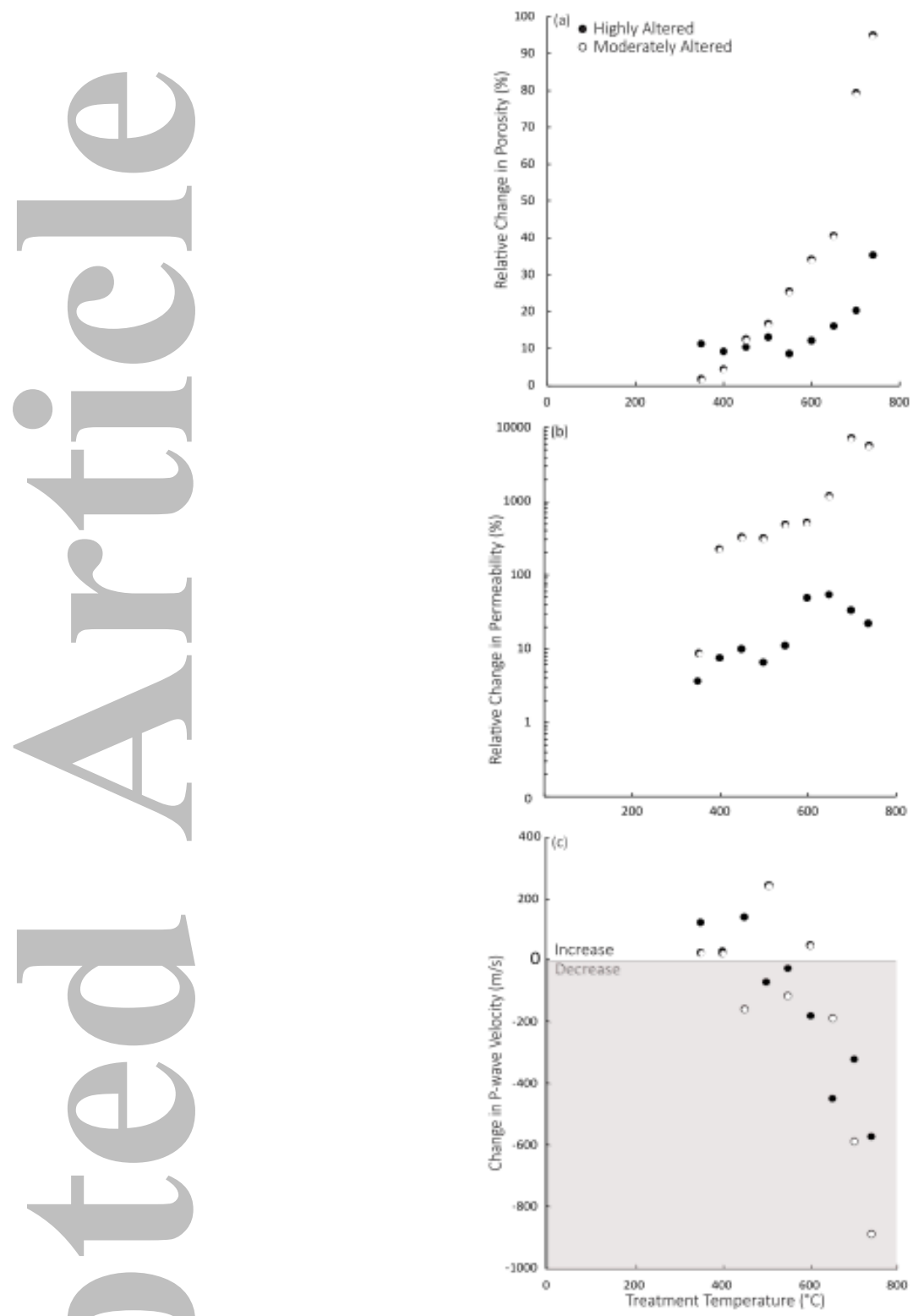

Figure 8. Changes in rock properties by treatment temperature. (a) Change in porosity following thermal treatment relative to initial porosity versus treatment temperature. Higher treatment temperature is associated with greater changes in porosity. (b) Change in permeability following thermal treatment relative to initial permeability versus treatment temperature. Treatment temperatures increases permeability more in the moderately altered samples than in the highly altered samples. (c) Change in P-wave velocity versus temperature. Treatment temperature decreases ultrasonic P-wave velocity in the moderately and highly altered Rotokawa andesite at $>600^{\circ} \mathrm{C}$. Standard Error $\leq 1 \%$ of the reported values. 


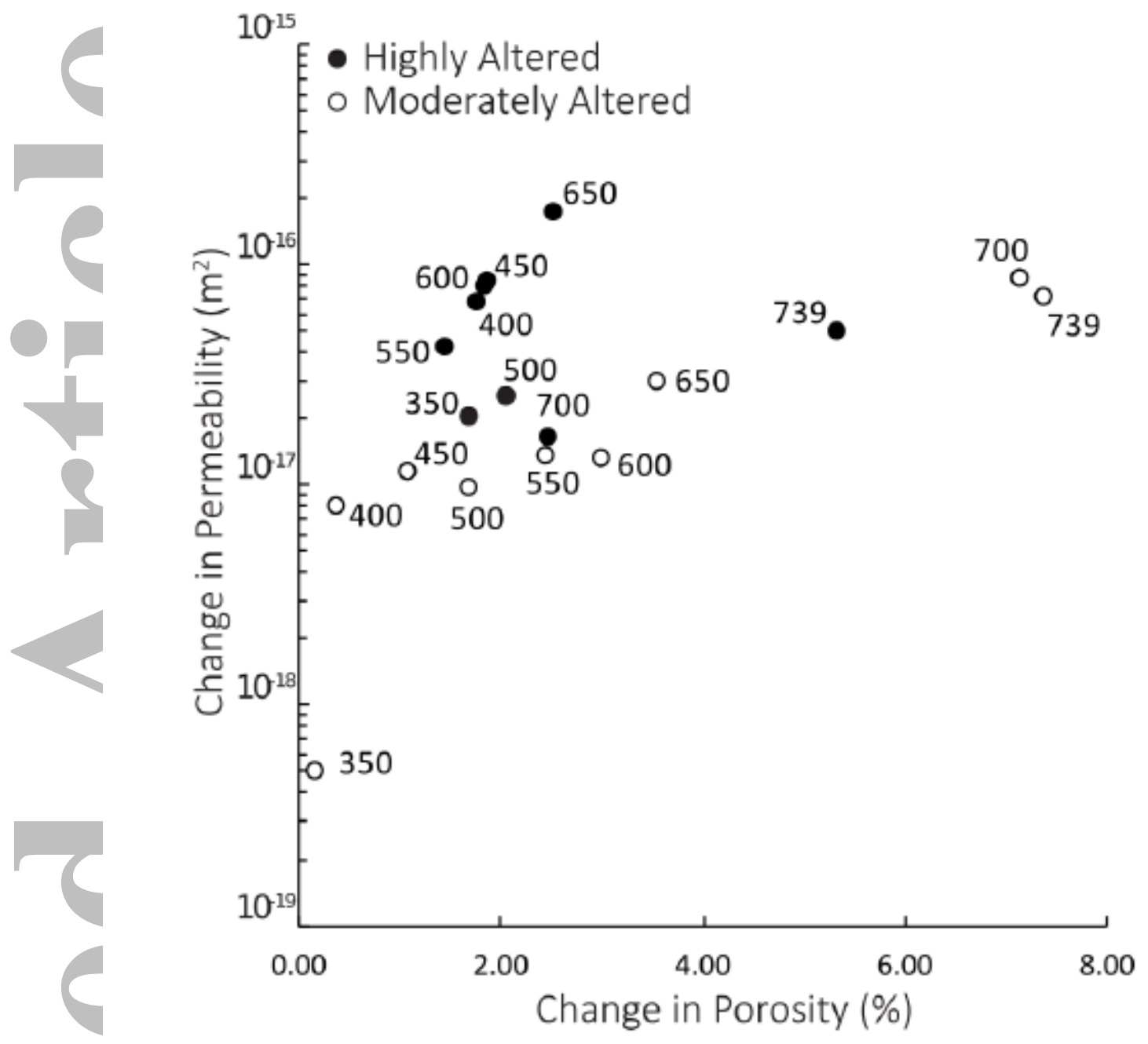

Figure 9. Change in porosity versus change in permeability. Change is given as the difference between initial and post-treatment values. Treatment temperatures provided adjacent to respective data points in ${ }^{\circ} \mathrm{C}$. Standard Error $\leq 1 \%$ of the reported values. 